\title{
Controlling In Vitro Insulin Amyloidosis with Stable Peptide Conjugates: A Combined Experimental and Computational study
}

\author{
Narendra Kumar Mishra, ${ }^{a}$ R. N. V. Krishna Deepak ${ }^{\mathrm{b}}$, Ramasubbu \\ Sankararamakrishnan ${ }^{* b}$ Sandeep Verma ${ }^{{ }^{a}}$ \\ ${ }^{a}$ Department of Chemistry, DST Thematic Unit of Excellence on Soft Nanofabrication, Indian Institute of \\ Technology Kanpur, Kanpur-208016 (UP), India. E-mail: sverma@,iitk.ac.in \\ ${ }^{\mathrm{b}}$ Department of Biological Science and Bioengineering Indian Institute of Technology Kanpur, Kanpur-208016 \\ (U.P),India. Email: rsankar@iitk.ac.in
}

\section{SUPPORTING INFORMATION}

Peptide synthesis - All peptide conjugates were synthesized by established lab protocol ${ }^{1,2}$ by simple solution phase fragment condensation methodologies using $t$-Boc chemistry and in the presence of HOBt. Purity of final products was checked by analytical RP-HPLC (conditions for all purifications: $0.1 \%$ trifluoroacetic acid in water (eluent $\mathrm{A}$ ) to $0.1 \%$ trifluoroacetic acid in acetonitrile (eluent B) with the gradient $(0-60 \%$ of $\mathrm{B}$ in $45 \mathrm{~min})$, flow rate: $1 \mathrm{~mL} / \mathrm{min}$, column specification: Agilent's Eclipse $\mathrm{XDB}-\mathrm{C} 18,4.6 \times 250 \mathrm{~mm}$ at RT). The purity and identity of the all peptide conjugates were confirmed by HRMS. Concentration of all peptide conjugates for a typical analytical run was $\sim 2 \mathrm{mg} / \mathrm{mL}$. (Figure S2S5).
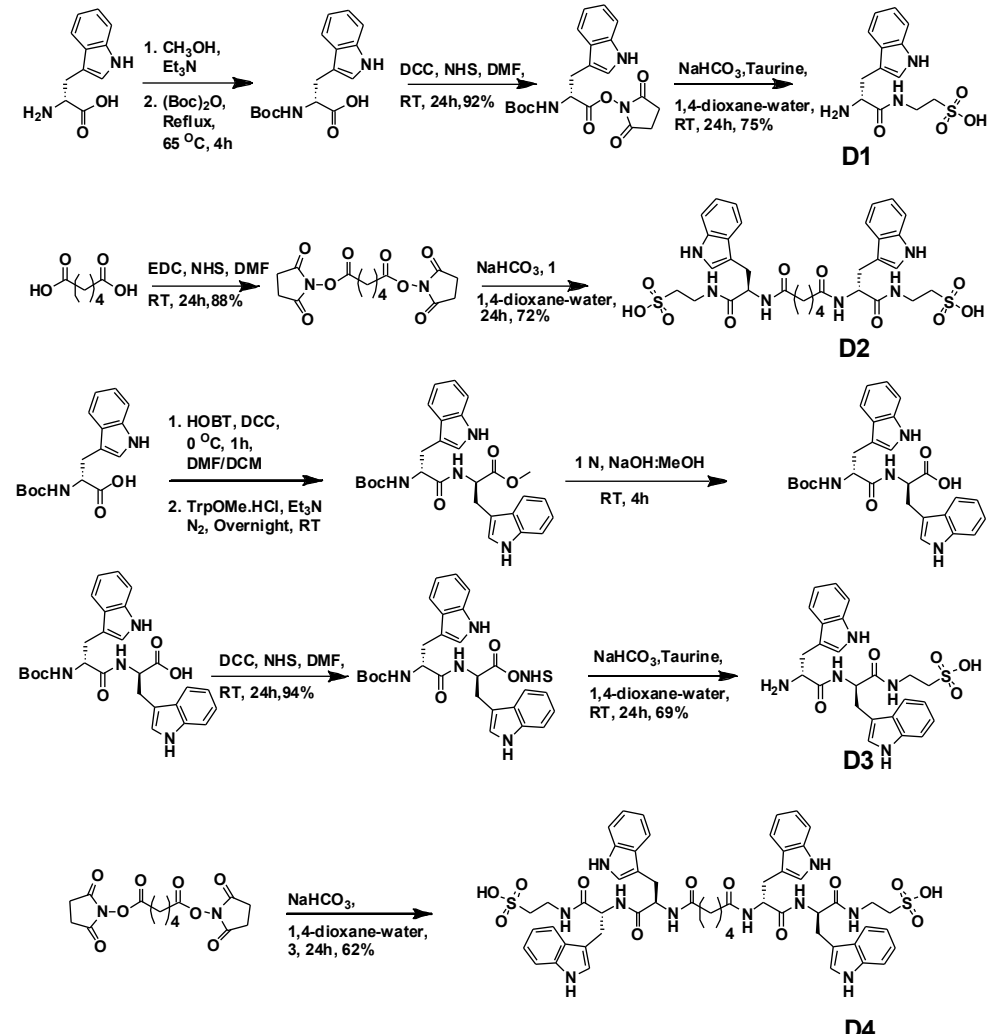
Scheme S1: Synthetic scheme of peptide conjugates D1, D2, D3 and D4.

\begin{abstract}
Synthesis of $N$-tert-butyloxycarbonyl-D-Tryptophan, $N$-tert-butyloxycarbonyl-di-D-Trytophan methyl ester and $N$-tert-butyloxycarbonyl-di-D-Trytophan: These peptide conjugates were synthesized via using standard lab protocols ${ }^{1,2}$ followed by purification and characterization and used for further steps wherever needed (scheme S1).
\end{abstract}

N-tert-butyloxycarbonyl D-tryptophan-NHS- $N$-tert-butyloxycarbonyl D-tryptophan $(3.0 \mathrm{~g}, 9.87$ mmol), N-hydroxysuccinimide $(1.36 \mathrm{~g}, 11.82 \mathrm{mmol})$ was dissolved in mixture of DCM $(80 \mathrm{~mL})$ and DMF (4 mL) and the reaction mixture was cooled to $0{ }^{\circ} \mathrm{C}$ under nitrogen atmosphere. Solution of N-N dicyclohexylcarbodiimide $(2.43 \mathrm{~g}, 11.82 \mathrm{mmol})$ in $\mathrm{DCM}(30 \mathrm{~mL})$ was added into the reaction mixture and allowed to stir for $4 \mathrm{~h}$ at $0{ }^{\circ} \mathrm{C}$ followed by overnight stirring at room tempertaure. Next day the reaction mixture was filtered off and the filtrate was concentrated under reduced pressure. The crude product was diluted with dichloromethane and washed with $1 \mathrm{~N} \mathrm{HCl}(3 \times 50 \mathrm{~mL})$ followed by sodium bicarbonate solution $(3 \times 50 \mathrm{~mL})$ and further with brine solution $(3 \times 50 \mathrm{~mL})$. Organic layer was dried over anhydrous sodium sulfate and concentrated to give crude product (Yield: $3.53 \mathrm{~g}, 87 \%$ ). The crude was directly used for the synthesis of next step.

D-Tryptophan-Taurine, ${ }^{4}$ D1- To the stirred solution of NHS ester of $N$-tert-butyloxycarbonyl Dtryptophan $3.5 \mathrm{~g}, 8.71 \mathrm{mmol})$ in 1,4 di-oxane $(40 \mathrm{~mL})$, taurine $(1.09 \mathrm{~g}, 4.98 \mathrm{mmole})$ and sodium bicarbonate $(1.5 \mathrm{~g}, 17.42 \mathrm{mmol})$ dissloved in water $(40 \mathrm{~mL})$ was added and the reaction mixture was allowed to stir at RT for 24 hours. The reaction mixture was passed through the strong cation exchange resin (Amberlite IR 120) and the solution was evaportaed to dryness to get the crude product. Crude product was further purified with silica gel column chromatrography by dichloromethane : methanol (85:15) to get the pure product 1 . $\mathrm{R}_{\mathrm{f}}$ value 0.3 in $20 \%$ Methanol/DCM. Yield: $2.17 \mathrm{~g}(81 \%)$. M.P. 138 $139{ }^{\circ} \mathrm{C} ;[\alpha]_{\mathrm{D}}^{t}=-37.9$ (c 0.833 in $\left.\mathrm{CH}_{3} \mathrm{OH}\right) ;{ }^{1} \mathrm{H}$ NMR: $\left(500 \mathrm{MHz}\right.$ DMSO- $\left.d_{6}, 25^{\circ} \mathrm{C}, \mathrm{TMS}\right) \delta(\mathrm{ppm})=$ 
2.49- $2.51\left(2 \mathrm{H}\right.$, merged with DMSO- $d_{6}$ signal), 2.95-3.02 (m, 2H), 3.11-3.15 (m, 2H), 3.79-3.81 (t, 1H, $\mathrm{J}=6.87 \mathrm{~Hz}), 6.95-6.98(\mathrm{t}, 1 \mathrm{H}, \mathrm{J}=7.45 \mathrm{~Hz}), 7.03-7.06(\mathrm{t}, 1 \mathrm{H}, \mathrm{J}=7.45 \mathrm{~Hz}), 7.15(\mathrm{~s}, 1 \mathrm{H}), 7.31-7.33(\mathrm{~d}$, $1 \mathrm{H}, \mathrm{J}=8.0 \mathrm{~Hz}), 7.58-7.59(\mathrm{~d}, 1 \mathrm{H}, \mathrm{J}=8.05 \mathrm{~Hz}), 8.35-8.36(\mathrm{br}, 1 \mathrm{H}$, amide $-\mathrm{NH}), 10.95$ (s, 1H, indolic $\mathrm{NH}) .{ }^{13} \mathrm{C}$ NMR $\left(125 \mathrm{MHz}, \mathrm{DMSO}-d_{6}, 25{ }^{\circ} \mathrm{C}, \mathrm{TMS}\right): \delta(\mathrm{ppm})=28.38,36.54,50.93,53.99,108.16$, $112.16,119.12,121.80,125.38,127.79,136.95,169.54$, HRMS-ESI: $\mathrm{m} / \mathrm{z}$ calcd for $\mathrm{C}_{13} \mathrm{H}_{18} \mathrm{~N}_{3} \mathrm{O}_{14} \mathrm{~S}$ $[\mathrm{M}+\mathrm{H}]^{+}=312.1018$; found: 312.1017 .

N-tert-butyloxycarbonyl-di-D-tryptophan-NHS:- $N$-tert -butyloxycarbonyl di-D-tryptophan (5.0 g, $10.19 \mathrm{mmol})$, N-hydroxysuccinimide $(1.4 \mathrm{~g}, 12.23 \mathrm{mmol})$ was dissolved in mixture of DCM (100 mL) and DMF (6 mL) and the reaction mixture was cooled to $0{ }^{\circ} \mathrm{C}$ under nitrogen atmosphere. Solution of $\mathrm{N}-\mathrm{N}$ dicyclohexylcarbodiimide $(2.5 \mathrm{~g}, 12.23 \mathrm{mmol})$ in $\mathrm{DCM}(30 \mathrm{~mL})$ was added into the reaction mixture and allowed to stirred for $4 \mathrm{~h}$ at $0{ }^{\circ} \mathrm{C}$ under $\mathrm{N}_{2}$ atmosphere followed by overnight stirring at room tempertaure. Next day the reaction mixture was filtered off and the filtrate was concentrated under reduced pressure. The crude product was diluted with dichloromethane and washed with $1 \mathrm{~N} \mathrm{HCl}(3 \mathrm{x}$ $50 \mathrm{~mL})$ followed by sodium bicarbonate solution $(3 \times 50 \mathrm{~mL})$ and further with brine solution $(3 \times 50$ $\mathrm{mL}$ ). Organic layer was dried over anhydrous sodium sulfate and concentrated to give crude product (Yield: $4.5 \mathrm{~g}, 76 \%$ ). The product was directly used for the synthesis of next step without further purification.

Bis NHS ester of Adipic acid ${ }^{5}$ - To the stirred solution of adipic acid (1.0 g, $\left.6.84 \mathrm{mmol}\right)$ in DMF (20 $\mathrm{mL})$ at $\quad 0 \quad{ }^{\circ} \mathrm{C}$, N-hydroxy succinimide $(3.0 \quad \mathrm{~g}, 27.36 \mathrm{mmol})$ and 1-ethyl-3(3dimethylminopropyl)carbodiimide (5.14 g, $27.36 \mathrm{mmole})$ was added and the reaction mixture was allowed to stir at RT for 24 hours. The rection mixture was evaporated under reduced pressure and crude was dissolved in acetone $(80 \mathrm{~mL})$ and poured into the $1 \mathrm{~N} \mathrm{HCl}(200 \mathrm{~mL})$. This rection mixture was set aside at room temperature for $1-2 \mathrm{~h}$ and the white precipitate was appeared. The precipitate was washed with distilled water $(2 \times 50 \mathrm{~mL})$ followed by hot isopropanol $(50 \mathrm{~mL})$. Precipitate was dried 
under high vaccum to get the pure prodouct. Yield: $2.0 \mathrm{~g}(88 \%) .{ }^{1} \mathrm{H}$ NMR: $\left(500 \mathrm{MHz} \mathrm{DMSO}-d_{6}, 25^{\circ} \mathrm{C}\right.$, TMS) $\delta(\mathrm{ppm}) 1.66-1.69(\mathrm{~m}, 4 \mathrm{H}) ; 2.69-2.72(\mathrm{t}, 4 \mathrm{H}, \mathrm{J}=6.6 \mathrm{~Hz}) ; 2.77(\mathrm{~s}, 8 \mathrm{H}) ;{ }^{13} \mathrm{C} \mathrm{NMR}(125 \mathrm{MHz}$, $\left.\mathrm{CDCl}_{3}, 25^{\circ} \mathrm{C}, \mathrm{TMS}\right): \delta(\mathrm{ppm})=28.56,30.74,34.96,174.09,175.55$.

$\boldsymbol{N}, \boldsymbol{N}$-Bis-(D-Tryptophan-Taurine), D2 - Bis NHS ester of adipic acid (300 $\mathrm{mg}, 0.881 \mathrm{mmol}$ ) was dissolved in di-oxane $(20 \mathrm{~mL})$ followed by the solution of compound D-Tryptohan-Taurine (548 $\mathrm{mg}$, $1.762 .10 \mathrm{mmol})$ and sodium bicarbonate $(147 \mathrm{mg}, 2.10 \mathrm{mmol})$ in water was addded to the reaction mixture The reaction mixture was allowed to stirr at RT for 24 hours under $\mathrm{N}_{2}$ atmosphare. After completion of reaction, the reaction mixture was passed through the strong cation exchange resin (Amberlite IR 120) and the solution was evaportaed to dryness to get the crude product. Crude product was further purified with silica gel column chromatrography by dichloromethane methanol $(80: 20)$ to get the pure product 2. $\mathrm{R}_{\mathrm{f}}=0.3$ in $30 \%$ Methanol/DCM. Yield: $450 \mathrm{mg}(74 \%)$, M.P. $138.0-139.0{ }^{\circ} \mathrm{C}$; $[\alpha]_{\mathrm{D}}^{t}=19.67\left(\mathrm{c} 0.83\right.$ in $\left.\mathrm{CH}_{3} \mathrm{OH}\right) ;{ }^{1} \mathrm{H}$ NMR: $\left(500 \mathrm{MHz}\right.$ DMSO- $\left.d_{6}, 25^{\circ} \mathrm{C}, \mathrm{TMS}\right): \delta(\mathrm{ppm})=1.24(\mathrm{bs}$, 4H), $1.97(\mathrm{~s}, 4 \mathrm{H}), 2.48-2.54(\mathrm{~m}, 4 \mathrm{H}), 2.81-2.86(\mathrm{~m}, 2 \mathrm{H}), 3.07-3.10(\mathrm{~m}, 4 \mathrm{H}), 4.35\left(\mathrm{~m}, 2 \mathrm{H}, \operatorname{Trp} \alpha, \alpha^{\circ}\right)$, 6.90-6.93 (t, J = 7.45, 2H), 6.98-7.01 (m, 2H ), $7.06(\mathrm{~s}, 2 \mathrm{H}), 7.26(\mathrm{~d}, \mathrm{~J}=8 \mathrm{~Hz}, 2 \mathrm{H}), 7.50(\mathrm{~d}, \mathrm{~J}=7.50 \mathrm{~Hz}$, 2H), $7.93(\mathrm{~d}, \mathrm{~J}=8.6 \mathrm{~Hz}, 2 \mathrm{H}), 10.72(\mathrm{~s}, 2 \mathrm{H}$, indolic $-\mathrm{NH})$.

${ }^{13} \mathrm{C}$ NMR (125 MHz, DMSO- $\left.d_{6}, 25^{\circ} \mathrm{C}, \mathrm{TMS}\right): \delta(\mathrm{ppm})=25.00,28.16,35.33,36.02,50.77,54.10$, $110.87,111.76,118.63,121.25,123.98,127.73,136.52,171.68,172.51$, HRMS-ESI: $\mathrm{m} / \mathrm{z}$ calcd for $\mathrm{C}_{32} \mathrm{H}_{41} \mathrm{~N}_{6} \mathrm{O}_{10} \mathrm{~S}_{2}[\mathrm{M}+\mathrm{H}]^{+}=733.2326$; found: 733.2320 .

Di-D-tryptophan-Taurine, D3: - To the stirred solution of $N$-tert-butyloxycarbonyl- Di-D-tryptophanNHS (1.40 g, $2.38 \mathrm{mmol})$ in 1,4-dioxane $(30 \mathrm{~mL})$, Taurine $(298 \mathrm{mg}, 2.38 \mathrm{mmol})$ and sodium bicarbonate $(399 \mathrm{mg}, 4.76 \mathrm{mmol})$ were dissolved in water $(30 \mathrm{~mL})$ added to the reaction mixure. The reaction mixture was allowed to stir at RT under $\mathrm{N}_{2}$ atmosphare for $24 \mathrm{~h}$. After completion of reaction the crude was passed through the activated strong cation exchange resin (AMBERLITE IR120). Solution was evaporated to dryness and the crude compound was further purified by silica gel column 
chromatography by using dichloromethane:methanol (80:20) to get pure product $3 \mathrm{R}_{\mathrm{f}}=0.3$ in $30 \%$ Methanol/DCM. Yield: $1.1 \mathrm{~g}(86 \%)$. M.P. $183-185{ }^{\circ} \mathrm{C} ;[\alpha]_{\mathrm{D}}^{t}=4.87\left(\mathrm{c} 0.833\right.$ in $\left.\mathrm{CH}_{3} \mathrm{OH}\right)$; ${ }^{1} \mathrm{H}$ NMR: $\left(500 \mathrm{MHz}\right.$ DMSO- $\left.d_{6}, 25^{\circ} \mathrm{C}, \mathrm{TMS}\right) \delta(\mathrm{ppm})=2.48-2.51\left(2 \mathrm{H}\right.$, merged with DMSO- $d_{6}$ signal $), 2.87-2.92$ $(\mathrm{m}, 1 \mathrm{H}) 3.11-3.15(\mathrm{~m}, 2 \mathrm{H})$; 3.17-3.21 $(\mathrm{m}, 2 \mathrm{H}), 3.25-3.28\left(2 \mathrm{H}\right.$, merged with DMSO- $d_{6}$ residual water signal) 3.05-3.09 (m, 1H, Trp $\alpha \mathrm{H}) ; 3.76(1 \mathrm{H}, \operatorname{Trp} \alpha \mathrm{H}) ; 4.41(\mathrm{~m}, 1 \mathrm{H}), 6.89-6.92(\mathrm{~m}, 2 \mathrm{H}$, Ar-Trp-H); 6.94-6.96 (m, 1H, Ar-Trp-H); 7.05 (s,1H, Ar-Trp-H); 7.12 (s, 1H, Ar-Trp-H); 7.27-7.32 (dd, 2H, J1 = 7.95Hz, J' $=16.5 \mathrm{~Hz}$, Ar-Trp-H); 7.48 (d, 1H, J = 7.95 Hz, Ar-Trp-H); 7.61(d, 1H, J = 7.35 Hz, Ar-Trp$\mathrm{H})$; 7.94-7.97 (m, 2H, J = 5.5 Hz, $-\mathrm{NH}_{2}$ ); 8.56-8.57(br, 1H, amide -NH); 10.80 (s, 1H, indolic -NH); $10.93\left(\mathrm{~s}, 1 \mathrm{H}\right.$, indolic -NH). ${ }^{13} \mathrm{C}$ NMR $\left(125 \mathrm{MHz}, \mathrm{DMSO}-d_{6}, 25^{\circ} \mathrm{C}, \mathrm{TMS}\right): \delta(\mathrm{ppm})=28.07,28.79$, $29.58,36.28,49.12,50.77,54.37,54.01,110.34,111.82,111.93,118.74,121.39,124.14,127.72$, 136.57, 136.79, 170.88 HRMS-ESI: m/z calcd for $\mathrm{C}_{24} \mathrm{H}_{28} \mathrm{~N}_{5} \mathrm{O}_{5}[\mathrm{M}+\mathrm{H}]^{+}: 498.1811$, found: 498.1811 .

$\boldsymbol{N}, \boldsymbol{N}$-Bis-( Di-D-tryptophan-Taurine), D4:- Bis NHS ester of adipic acid (250 mg, $0.734 \mathrm{mmol})$ was dissolved in di-oxane $(20 \mathrm{~mL})$ followed by the solution of compound $3(731 \mathrm{mg}, 1.46 \mathrm{mmole})$ and sodium bicarbonate $(123 \mathrm{mg}, 1.46 \mathrm{mmole})$ in water $(20 \mathrm{~mL})$ was addded to the reaction mixture. The reaction mixture was allowed to stir at $\mathrm{RT}$ under $\mathrm{N}_{2}$ atmosphare for $24 \mathrm{~h}$. After completion of reaction mixture the crude was passed through the strong cation exchange resin (Amberlite IR 120) and solution was evaportaed to dryness to get the crude product. Crude product was further purified with silica gel column chromatrography by dichloromethane: methanol (70:30) to obtained the pure product 4 . $\mathrm{R}_{\mathrm{f}}$ value 0.4 in $40 \%$ Methanol/DCM. Yield: $410 \mathrm{mg}(50 \%)$. M.P. $205-207{ }^{\circ} \mathrm{C} ;[\alpha]_{\mathrm{D}}^{t}=24.48(\mathrm{c} 0.833$ in $\left.\mathrm{CH}_{3} \mathrm{OH}\right) ;{ }^{1} \mathrm{H} \mathrm{NMR}\left(500 \mathrm{MHz}, \mathrm{dmso}_{6},{ }_{6} 5^{\circ} \mathrm{C}, \mathrm{TMS}\right)=1.19(\mathrm{bs}, 4 \mathrm{H}) ; 1.92(\mathrm{bs}, 4 \mathrm{H}) ; 2.52-2.56(\mathrm{t}, 4 \mathrm{H}, \mathrm{J}$ $=9.15 \mathrm{~Hz}) ; 2.83-2.88(\mathrm{~m}, 2 \mathrm{H}) ; 2.91-2.95(\mathrm{~m}, 2 \mathrm{H}) ; 3.03-3.08(\mathrm{~m}, 3 \mathrm{H}) ; 3.12(\mathrm{bs}, 4 \mathrm{H}) ; 4.06-4.08(\mathrm{~m}, 1 \mathrm{H})$, 4.35-439(m, 2H); 4.44-4.46(m, 2H); 6.90-6.92(m, 2H, Ar-Trp-H), 6.98-7.01(m, 2H, Ar-Trp-H); 7.06 (bs, 2H, Ar-Trp-H); 7.25-7.27(m, 4H, Ar-Trp-H); 7.46-7.48(d, 2H, J = 7.75 Hz, Ar-Trp-H); 7.527.54(d, 2H, J = 7.75 Hz, Ar-Trp-H); 7.75-7.77(m, 2H, amide -NH), 7.87-7.89 (d, 2H, J = 7.95 Hz, amide $-\mathrm{NH}) ; 7.9-7.96(\mathrm{~d}, 2 \mathrm{H}, \mathrm{J}=7.9 \mathrm{~Hz}$ amide $-\mathrm{NH}) ; 10.73(\mathrm{~s}, 2 \mathrm{H}$, indolic $-\mathrm{NH}) ; 10.79(\mathrm{~s}, 2 \mathrm{H}$, indolic 
-NH). ${ }^{13} \mathrm{C}$ NMR $\left(125 \mathrm{MHz}, \mathrm{dmso}-d_{6}, 25{ }^{\circ} \mathrm{C}, \mathrm{TMS}\right):, \delta(\mathrm{ppm})=25.16,27.89,36.68,36.80,49.13,50.92$, $54.09,54.22,110.40,110.68,111.74,118.65,118.71,121.27,124.09,127.83,136.52,171.24,172.04$, 172.78 HRMS-ESI: $\mathrm{m} / \mathrm{z}$ calcd for $\left.\mathrm{C}_{54} \mathrm{H}_{59} \mathrm{~N}_{10} \mathrm{O}_{12} \mathrm{~S}_{2}[\mathrm{M}+\mathrm{H}]\right]^{-}: 1105.3912$, found: 1105.3916 .

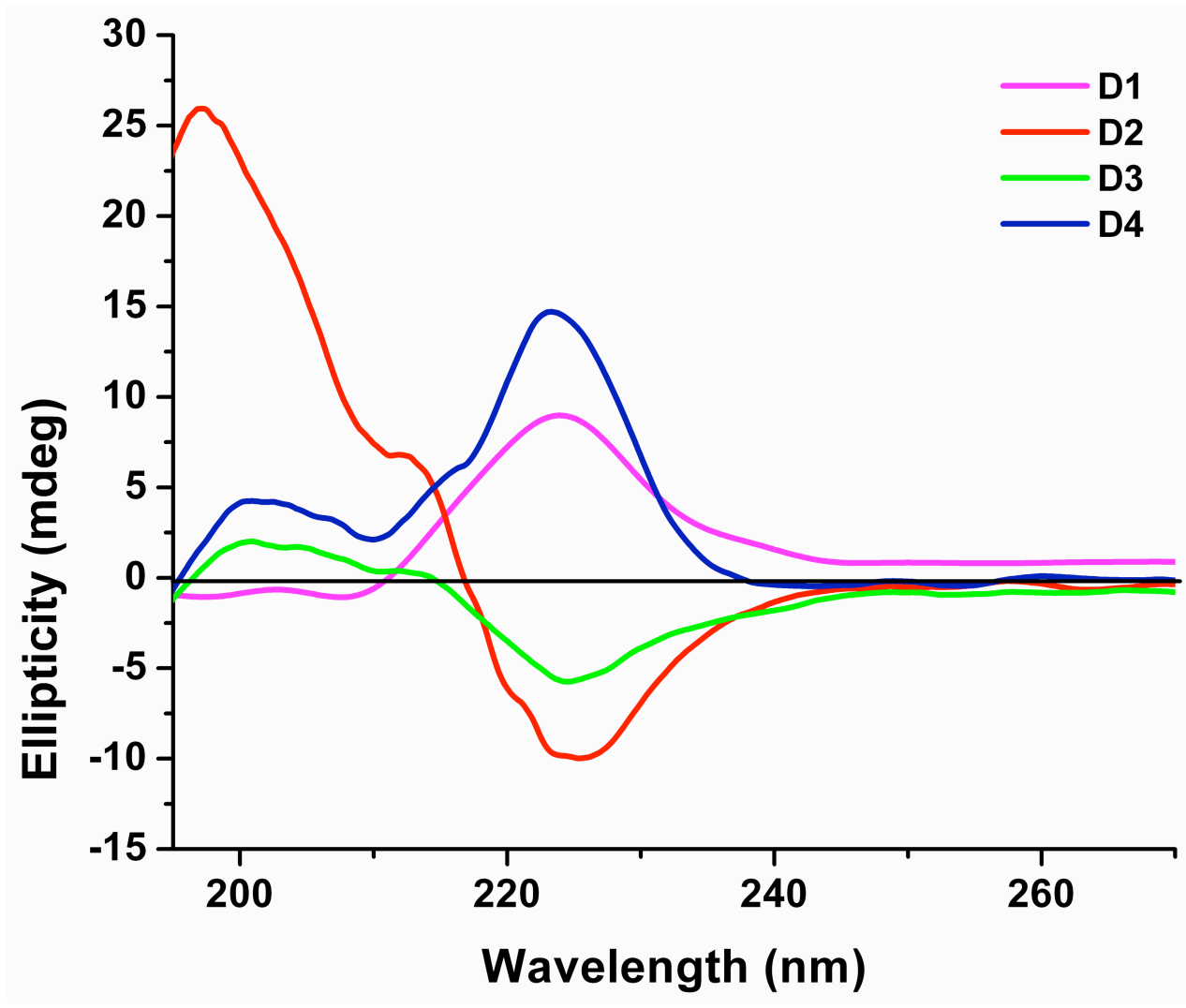

Figure S1 : UV Vis CD spectra for peptide D1-D4 (100 $\mu \mathrm{M})$ 


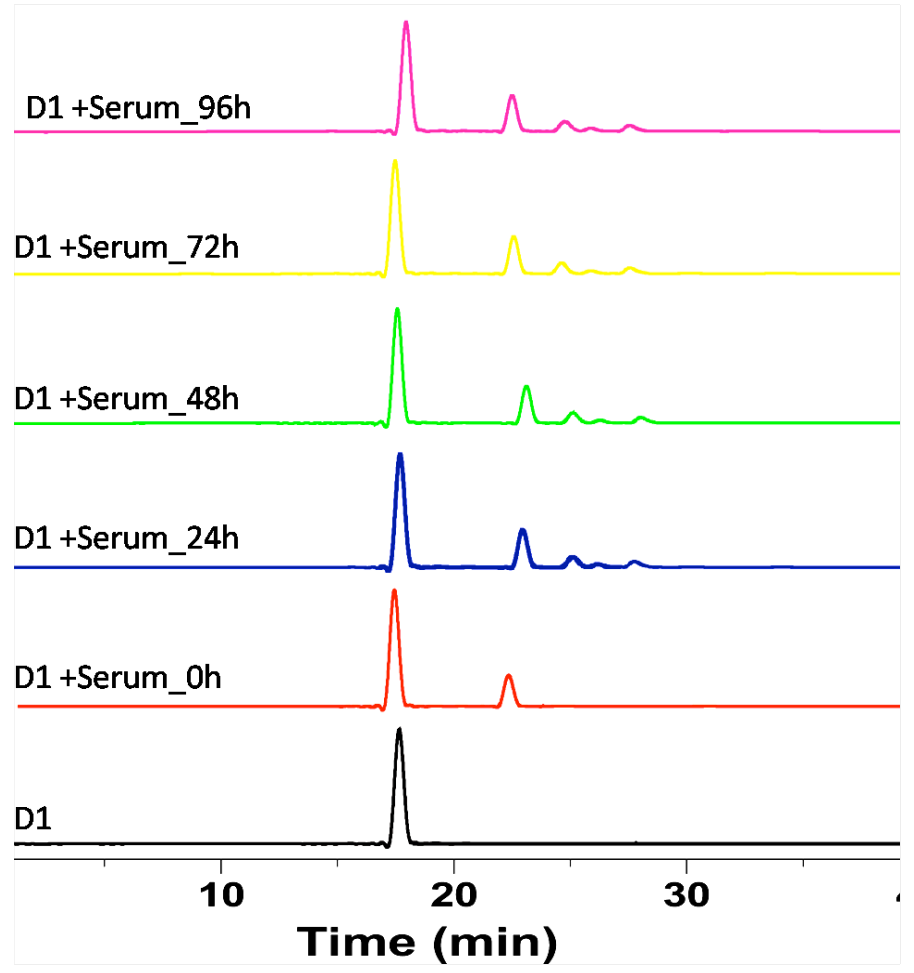

Figure S2: HPLC Traces of Peptide D1 in serum condition at different Time point.

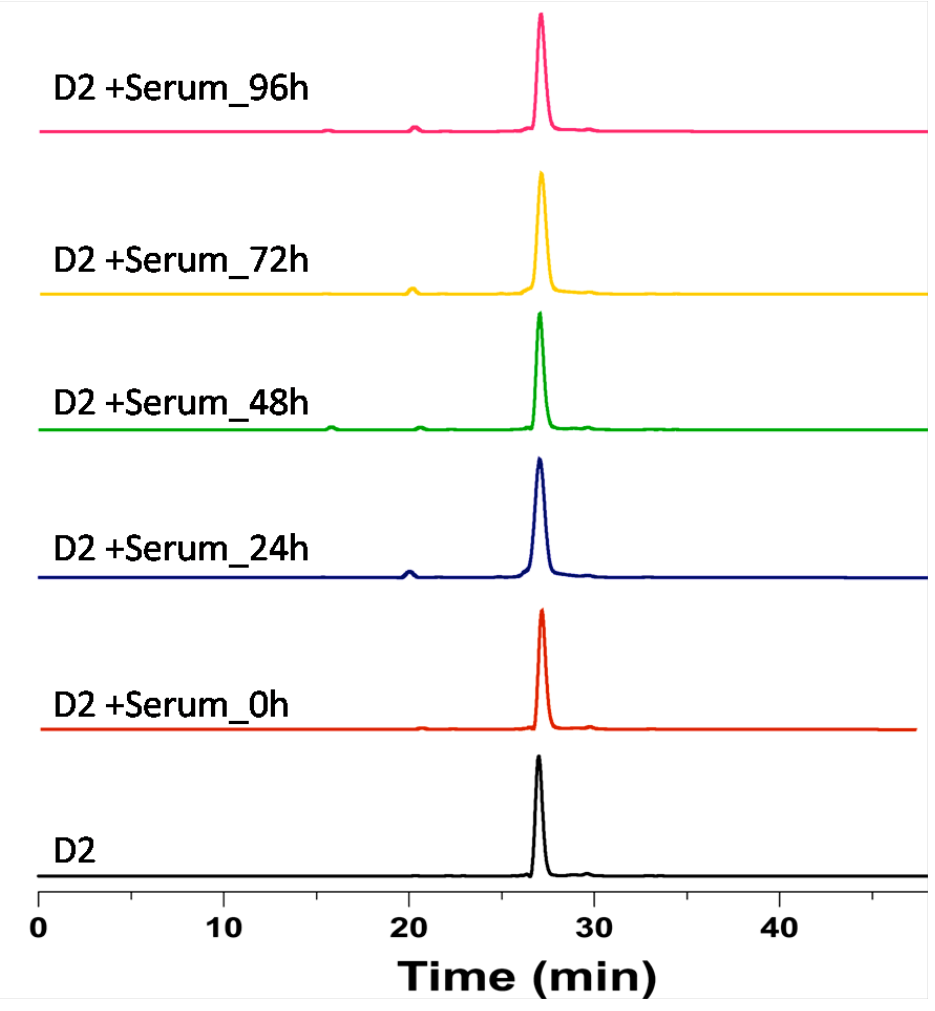

Figure S3: HPLC Traces of Peptide D2 in serum condition at different Time point. 


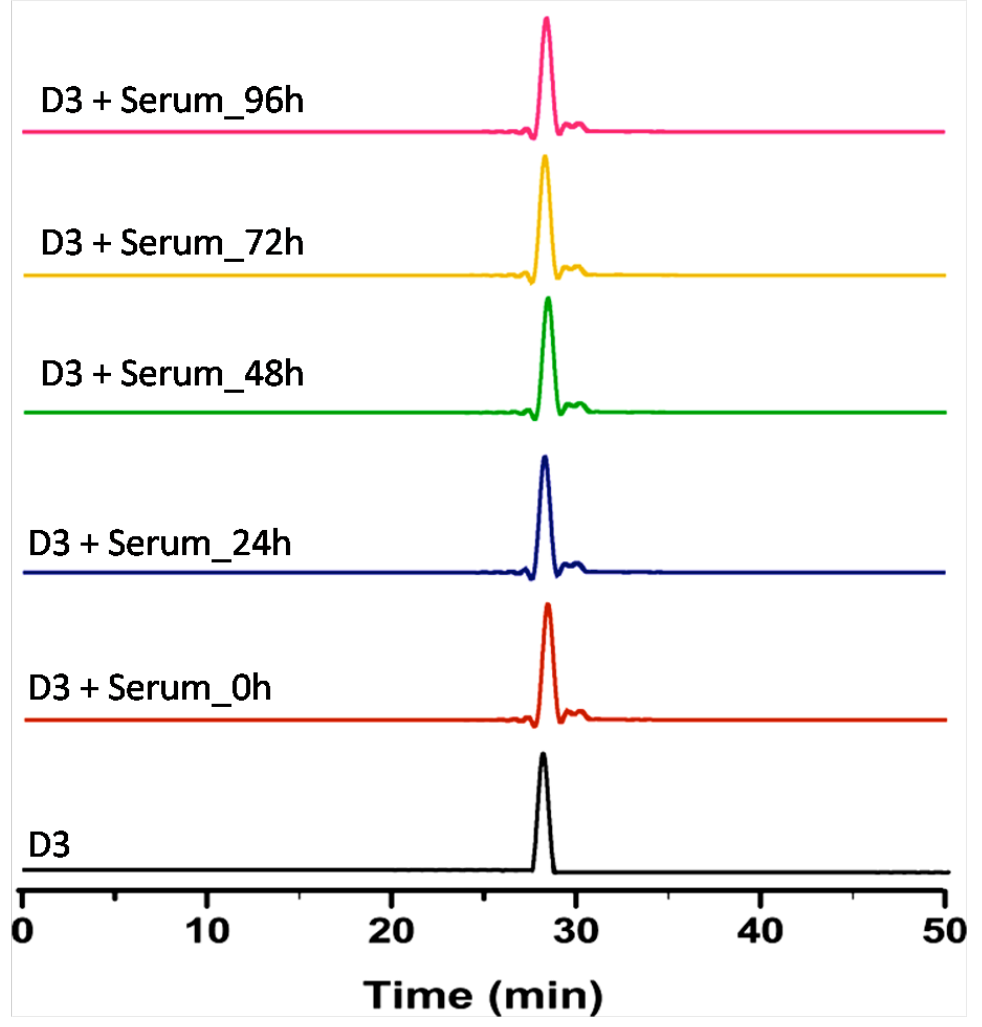

Figure S4: HPLC Traces of Peptide D3 in serum condition at different Time point.

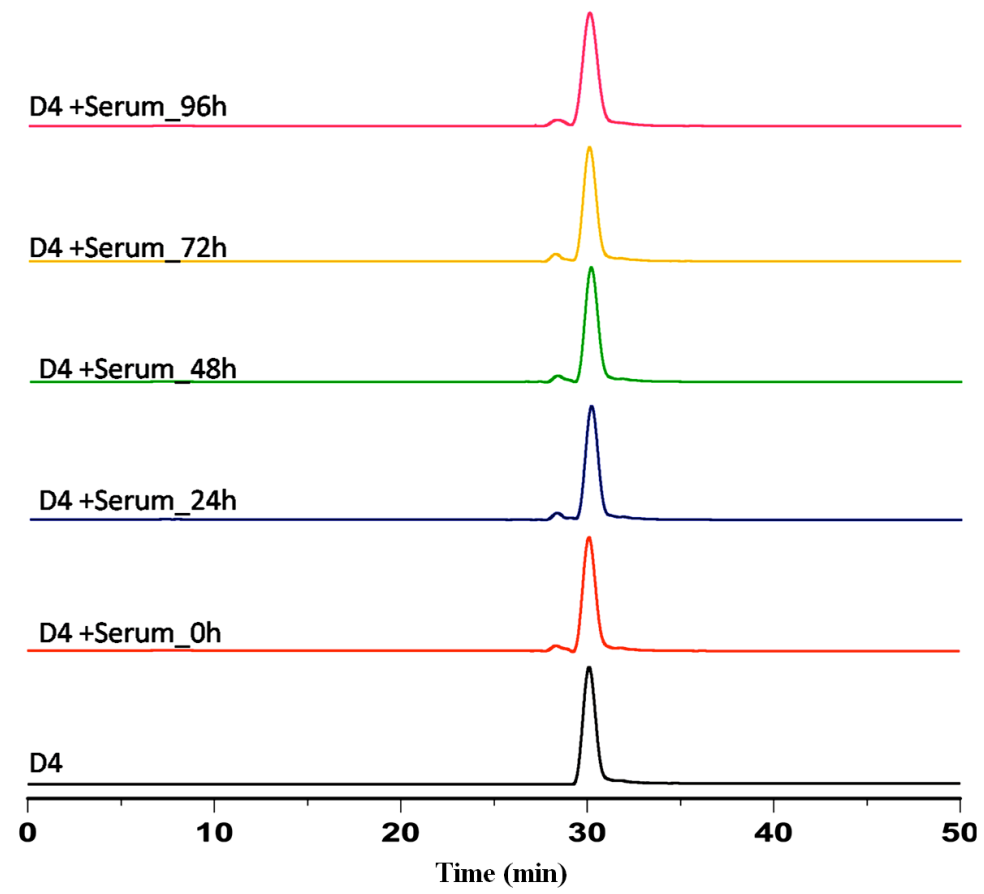

Figure S5: HPLC Traces of Peptide D4 in serum condition at different Time point. 

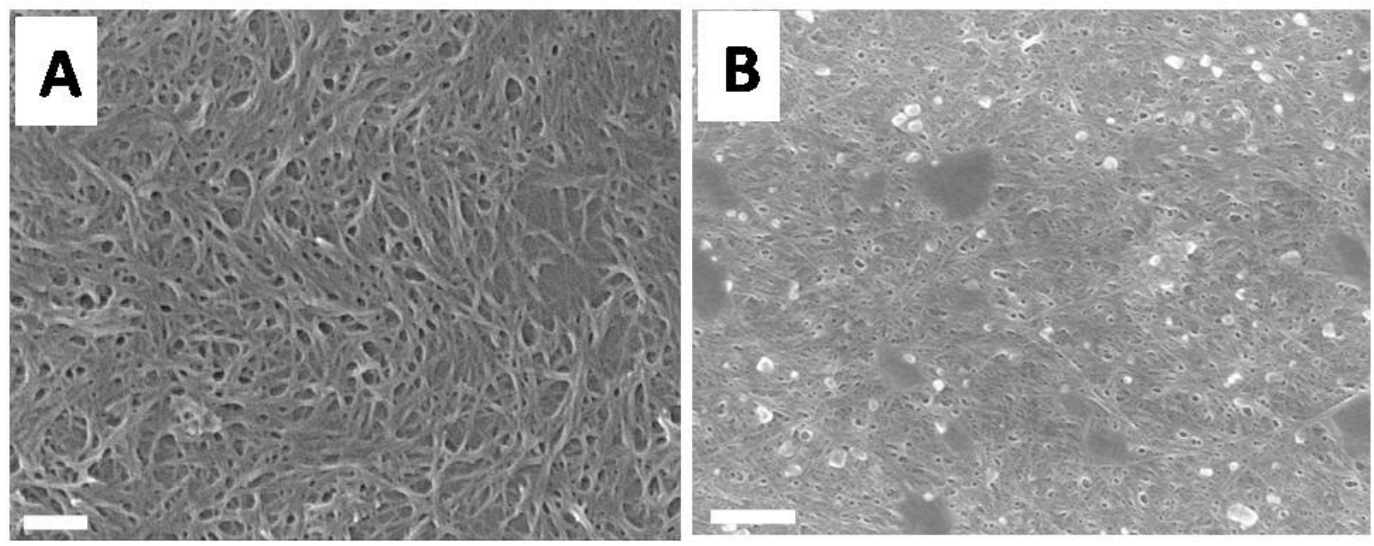

Figure S6 SEM micrograph of BI (A) and HI (B) alone and after 15 hours of incubation (Scale bar $200 \mathrm{~nm}$ ) in pH 1.6 at $65^{\circ} \mathrm{C}$.

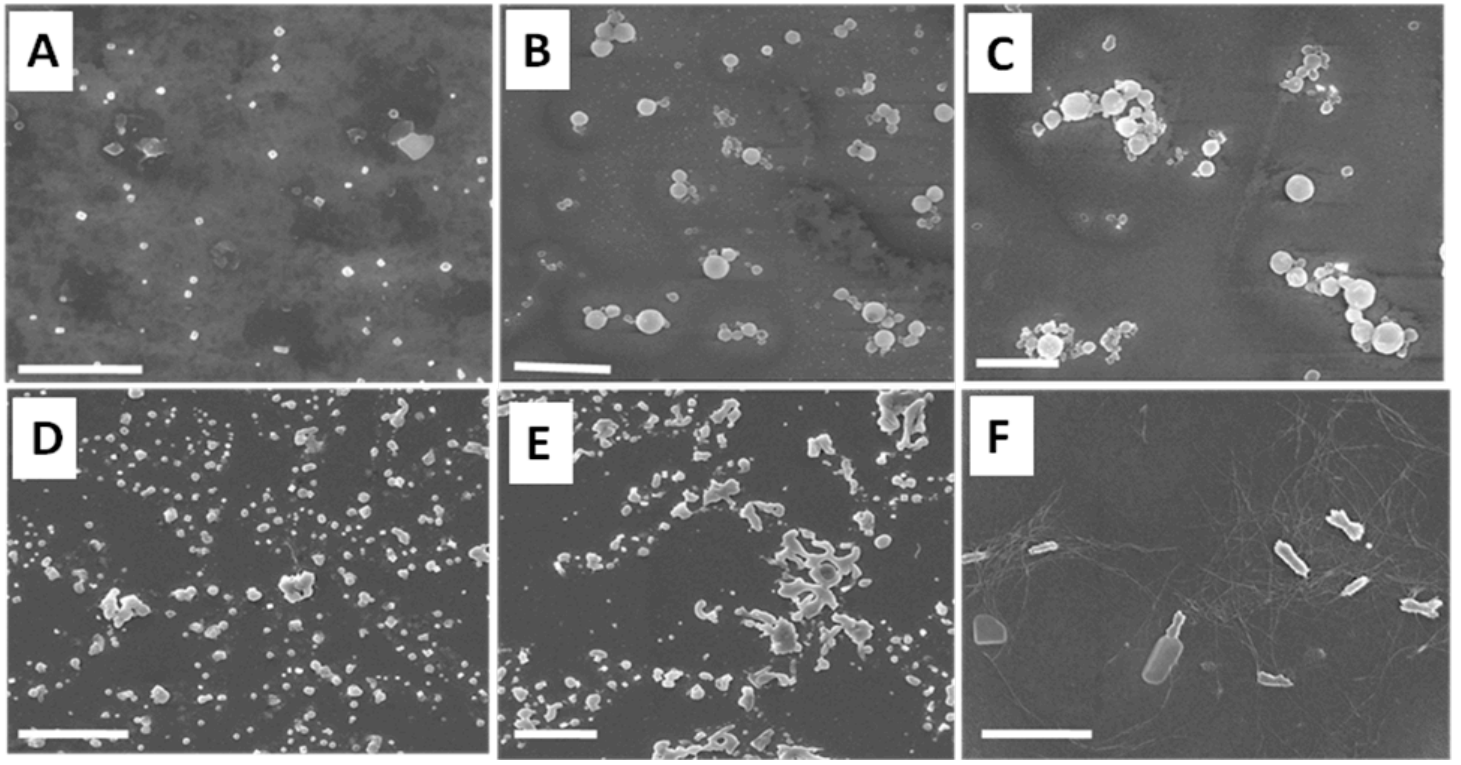

Figure S7: SEM micrograph of BI with Peptide conjugate D4 at different time interval (A) 0h (B) 10h (C) $20 \mathrm{~h}$ (D) $30 \mathrm{~h}(\mathrm{E}) 40 \mathrm{~h}(\mathrm{~F}) 50 \mathrm{~h}($ Scale bar $2 \mu \mathrm{m})$ in $\mathrm{pH} 1.6$ at $65^{\circ} \mathrm{C}$.

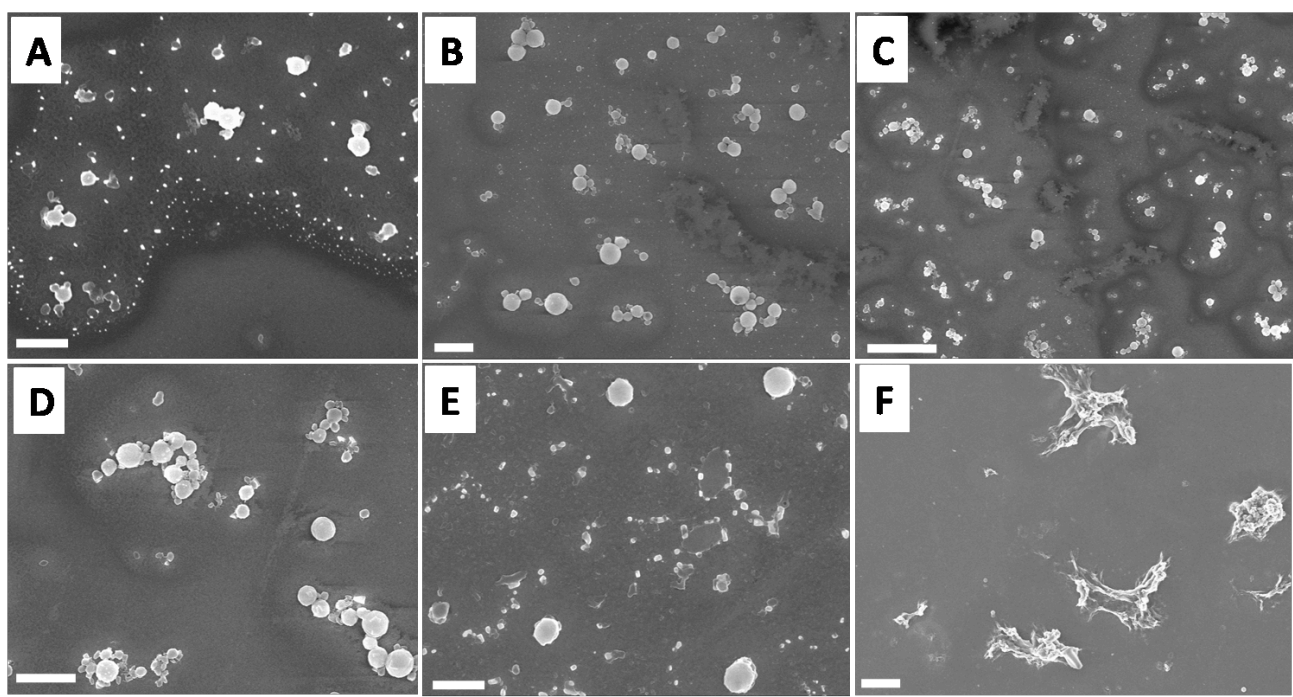


Figure S8: SEM micrograph of HI with Peptide conjugate D4 at different time interval (A) 0h (B) 10h (C) $20 \mathrm{~h}$ (D) $30 \mathrm{~h}(\mathrm{E}) 40 \mathrm{~h}(\mathrm{~F}) 50 \mathrm{~h}($ Scale bar $2 \mu \mathrm{m})$ in $\mathrm{pH} 1.6$ at $65^{\circ} \mathrm{C}$.

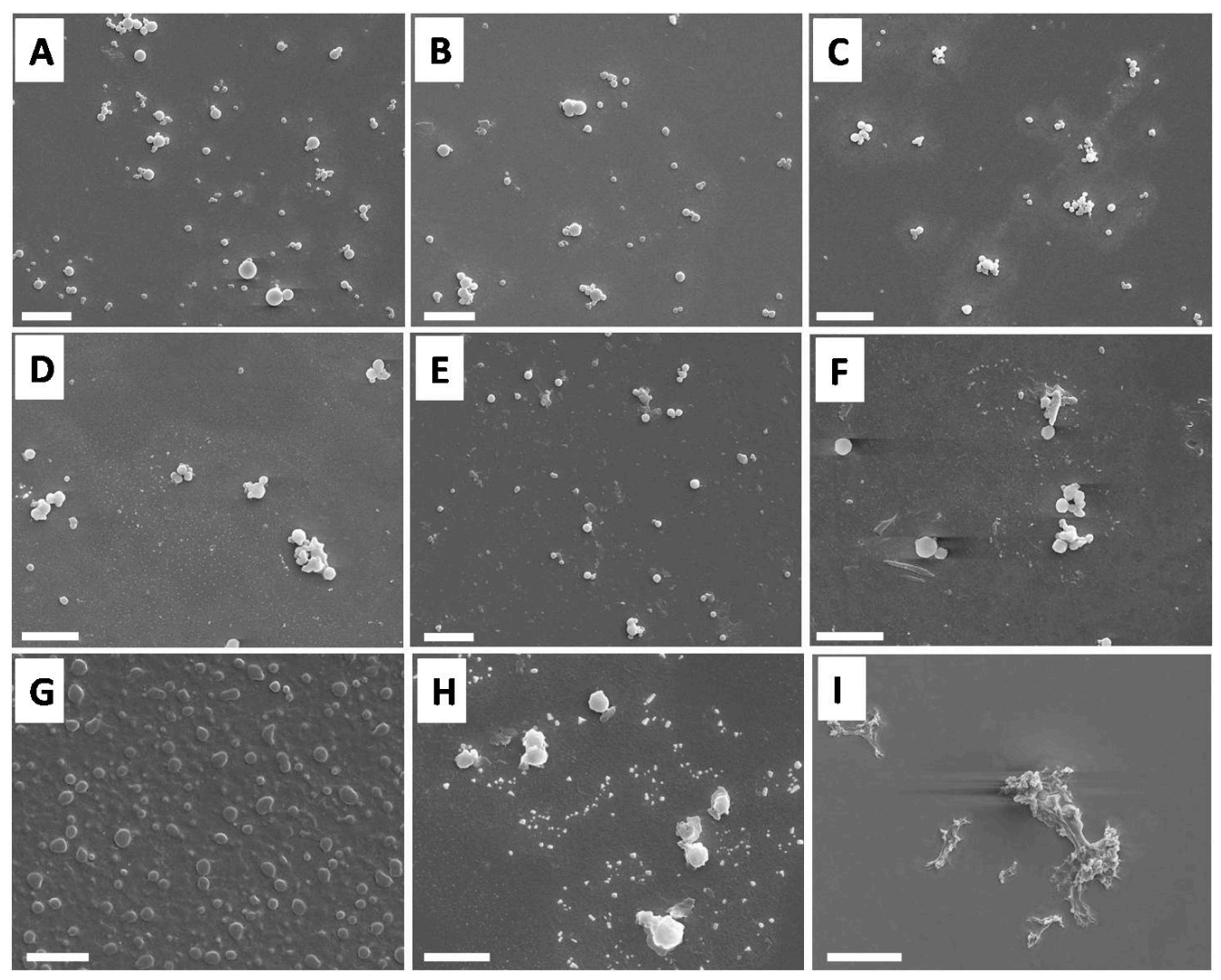

Figure S9: SEM microraph of HI with Peptide conjugate D4 (200 $\boldsymbol{M M})$ at different time interval (A) 0h (B) 10h (C) 20h (D) 30h (E) 40h (F) 50h (G) 60h (H) 70h (I) 80h (Scale bar $2 \mu \mathrm{m}$ ) in pH 1.6 at $65^{\circ} \mathrm{C}$
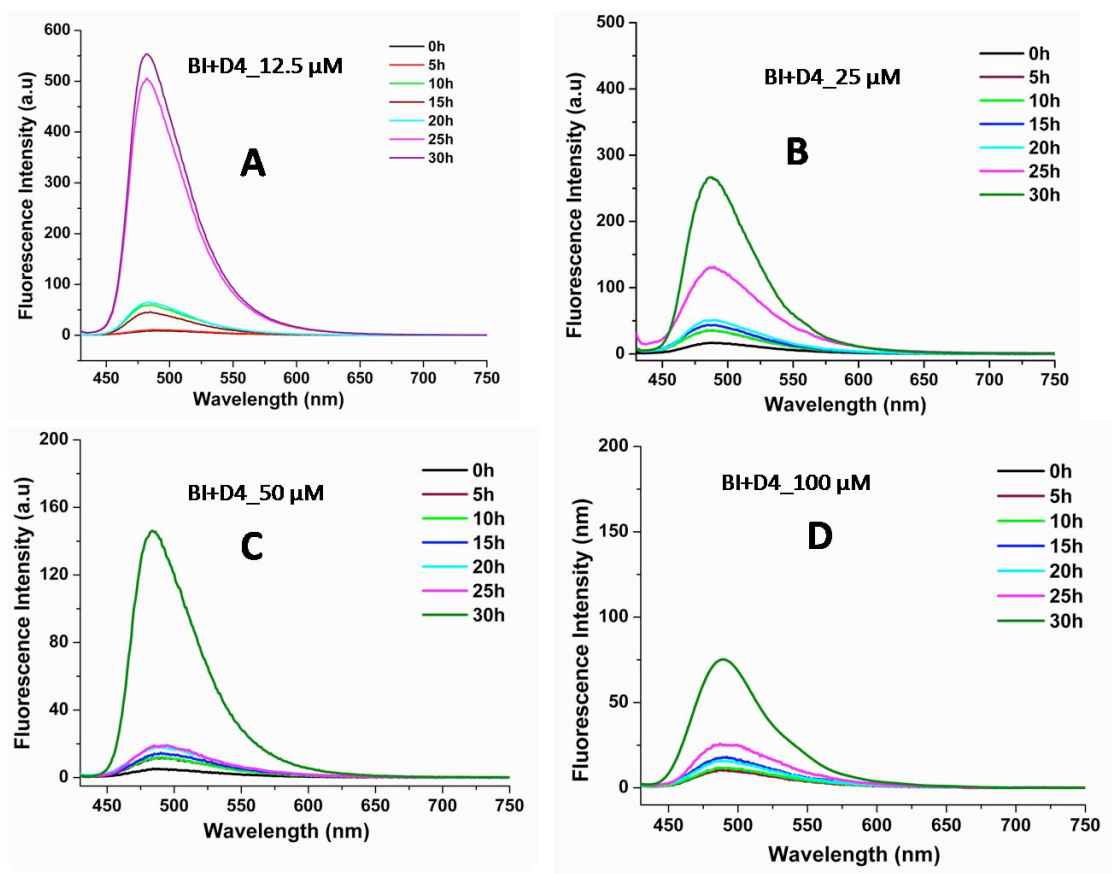
Figure S10: ThT Fluorescence spectra of Bovine insulin in presence of peptide D4 at different concentration (A). $12.5 \mu \mathrm{M}$ (B). $25 \mu \mathrm{M}$ (C). $50 \mu \mathrm{M}$ (D). $100 \mu \mathrm{M}$. $\left(\lambda_{\mathrm{ex}}=410 \mathrm{~nm} ; \lambda_{\mathrm{em}}=488 \mathrm{~nm}\right)$
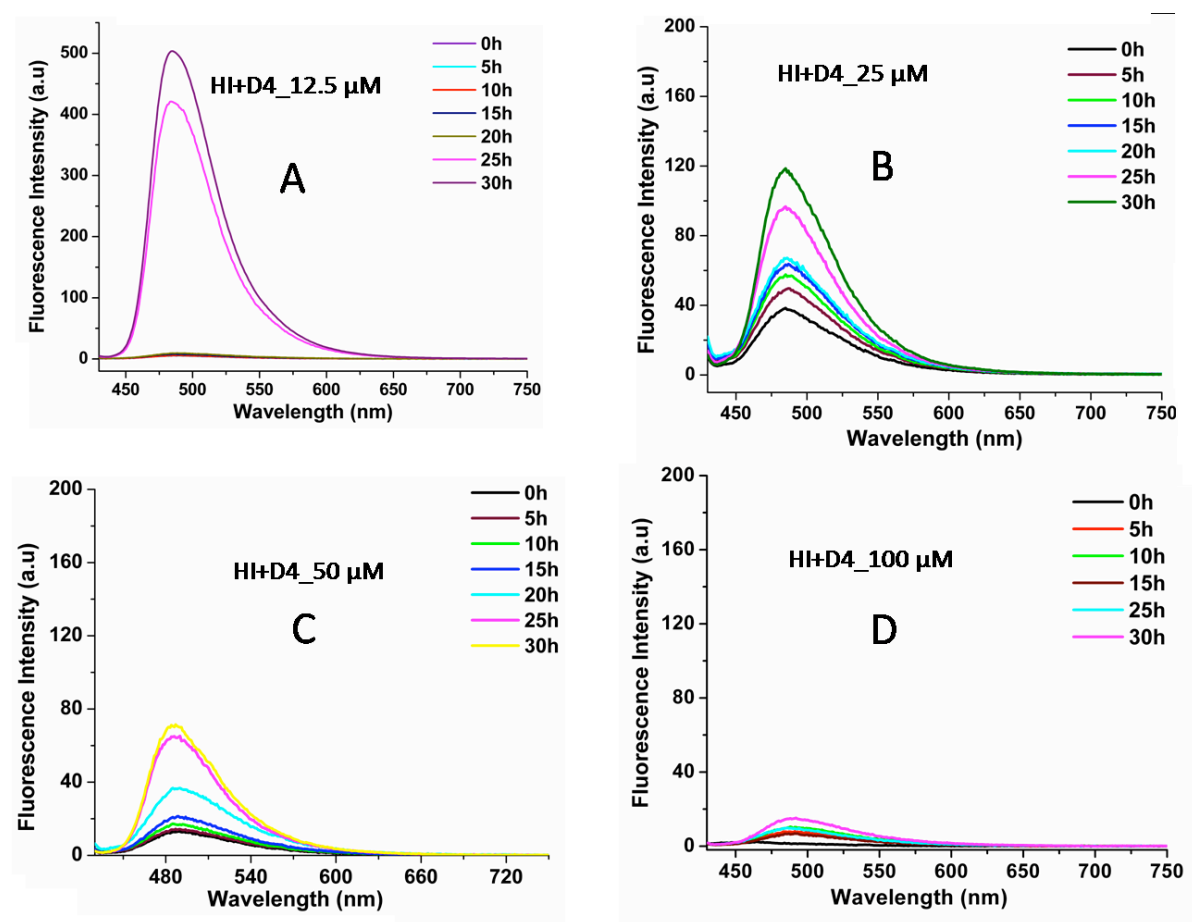

Figure S11: ThT Fluorescence spectra of Human insulin in presence of peptide D4 at different concentration (A). $12.5 \mu \mathrm{M}$ (B). $25 \mu \mathrm{M}$ (C). $50 \mu \mathrm{M}$ (D). $100 \mu \mathrm{M}$. $\left(\lambda_{\mathrm{ex}}=410 \mathrm{~nm} ; \lambda_{\mathrm{em}}=488 \mathrm{~nm}\right)$.

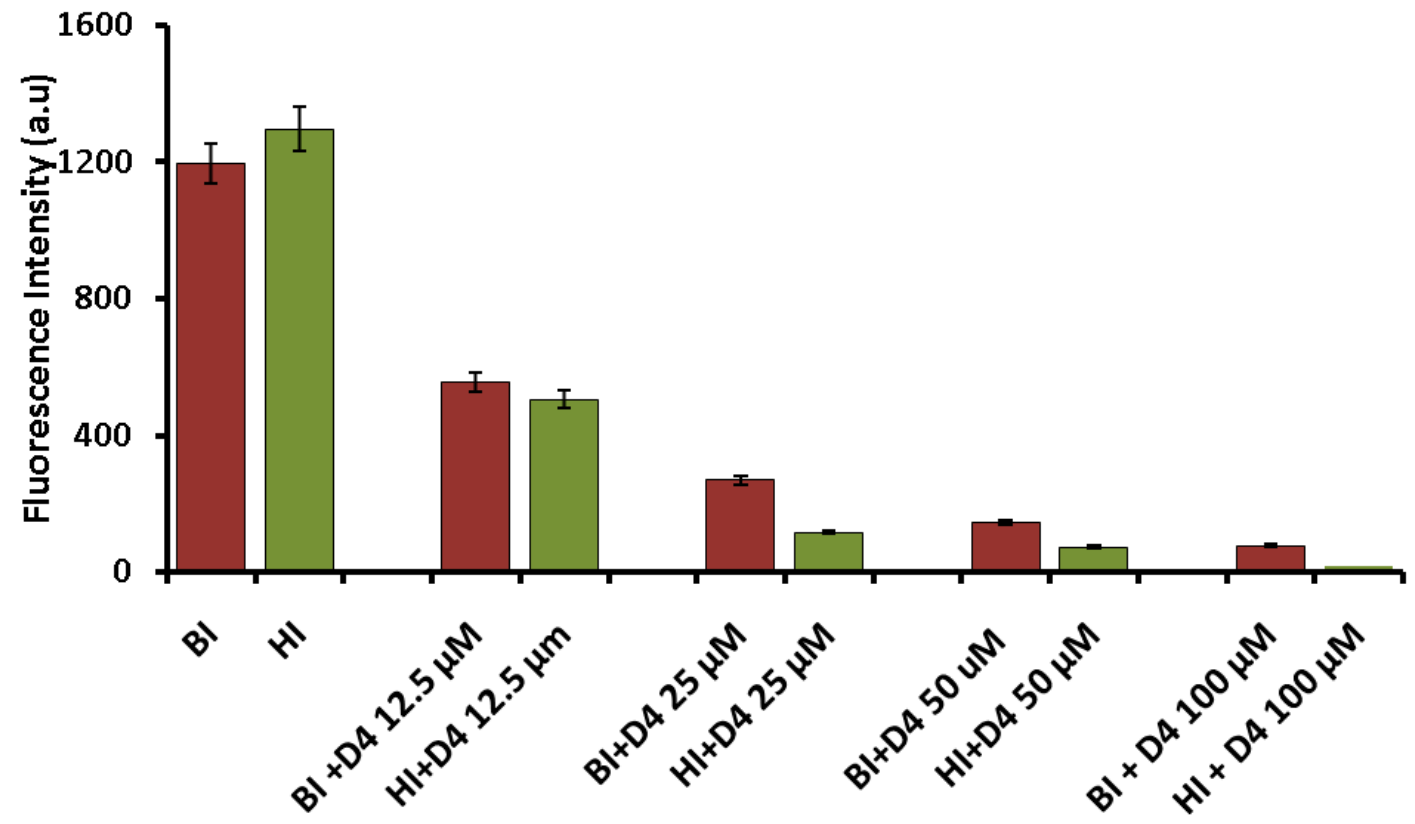

Figure S12 : Bar Diagram (ThT Fluorescence spectra) for the concentration dependent inhibitory effect of peptide D4 towards Insulin fibrillation after $30 \mathrm{~h}$. 

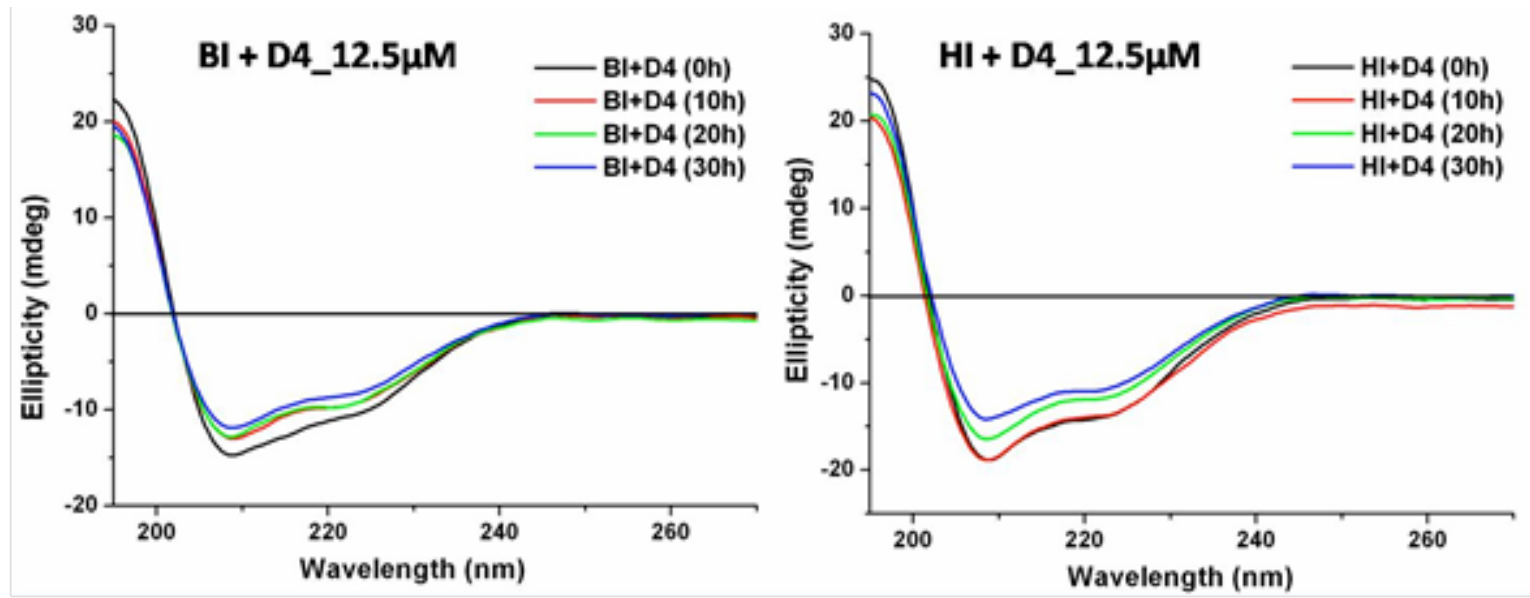

Figure S13: CD spectra of Left : BI and Right: HI upon addition of D4 (12.5 $\mu \mathrm{M})$.

Calculation of mean resdue ellipticity and \% helix of insulin alone and with peptide D4 $(100 \mu M):$

Mean residue ellipticity of the protein can be calculated by using the following equation. $^{7-8}$

$$
\text { Mean Residue Ellipticity }=\frac{\text { Observed CD }\left(\Theta_{o b s}\right)}{\text { Cp.n. } . .10}
$$

$\Theta_{\text {observed }}$ Observerd ellipticity at $222 \mathrm{~nm}$

$\mathrm{Cp}$ is the concentration of peptide

$\mathrm{n}$ is the number of peptide bonds

$l$ is the length of the path cell in $\mathrm{cm}$

To estimate the helical population of the sample at different time point, we have calculated it by using mean residue ellipticity at $222 \mathrm{~nm}$ as indicated in following equation.

$$
\% \text { Helix }=\frac{\Theta_{\text {mrw obser 222 }} \cdot 100}{\Theta_{\text {mw standard 222 }} \cdot(1-2.57 / n)}
$$


$\Theta_{\text {mrw obser 222 }}=$ observed mean residue ellipticity at $222 \mathrm{~nm}$

$\Theta$ mrw standard 222 = standard mean residue ellipticity of the peptide infinite length with $100 \%$ helix population

$\mathrm{n}=$ no of peptide bonds

Mean Residue ellipticity and \% helix at $222 \mathrm{~nm}$ is calculated for Human insulin (Table. 3 ) and bovine insulin (Table. 4) alone and with peptide D4 at different time point. $\% \alpha$ helix of $\mathrm{BI}$ and $\mathrm{HI}$ alone at 0 hour is 33.62 and $33.36 \%$ which is reduced to 12.67 and $9.31 \%$ after 10 hour of incubation in amyloidosis condition. However in presence of peptide D4, BI and $\mathrm{HI}$ showed the $\% \alpha$ helix $17.50 \%$ and $19.68 \%$ respectively after 50 hour of incubation.

Table 3: Calculated mean residue ellipticity and $\% \alpha$ helix of human insulin

\begin{tabular}{|c|c|c|c|}
\hline & Ellipticity & $\begin{array}{c}\text { Mean Residue } \\
\text { ellipticity } \\
\left.{\text { (deg } \mathbf{~ m}^{2} \mathbf{~ d m o l}^{-}}^{\mathbf{1}}\right)\end{array}$ & \% Helix \\
\hline HI (0h) & -10.6524 & $-1.25 \times 10^{4}$ & 33.62 \\
\hline HI (10h) & -2.96766 & $-3.49 \times 10^{3}$ & 9.31 \\
\hline HI + D4 (0h) & -9.45753 & $-1.1 \times 10^{4}$ & 29.35 \\
\hline HI + D4 (10h) & -8.22611 & $-9.67 \times 10^{3}$ & 25.80 \\
\hline HI + D4 (20h) & -6.88184 & $-8.09 \times 10^{3}$ & 22.12 \\
\hline HI + D4 (40h) & -6.77757 & $-7.97 \times 10^{3}$ & 21.59 \\
\hline HI + D4 (50h) & -6.36828 & $-7.49 \times 10^{3}$ & 19.98 \\
\hline
\end{tabular}


Table 4: Calculated mean residue ellipticity and $\% \alpha$ helix of bovine insulin

\begin{tabular}{|c|c|c|c|}
\hline & Ellipticity & $\begin{array}{c}\text { Mean Residue } \\
\text { ellipticity } \\
\left(\mathbf{d e g ~ c m}^{2} \mathbf{~ d m o l}^{-1}\right)\end{array}$ & \% Helix \\
\hline BI (0h) & -10.65039 & $-1.25 \times 10^{4}$ & 33.36 \\
\hline BI (10h) & -4.06831 & $-4.78 \times 10^{3}$ & 12.75 \\
\hline BI + D4 (0h) & -9.13269 & $-1.07 \times 10^{4}$ & 28.55 \\
\hline BI + D4 (10h) & -7.23175 & $-8.50 \times 10^{3}$ & 22.68 \\
\hline BI + D4 (20h) & -6.51723 & $-7.66 \times 10^{3}$ & 18.81 \\
\hline BI + D4 (40h) & -5.99972 & $-7.05 \times 10^{3}$ & 17.50 \\
\hline BI + D4 (50h) & -5.57701 & $-6.56 \times 10^{3}$ & \\
\hline
\end{tabular}




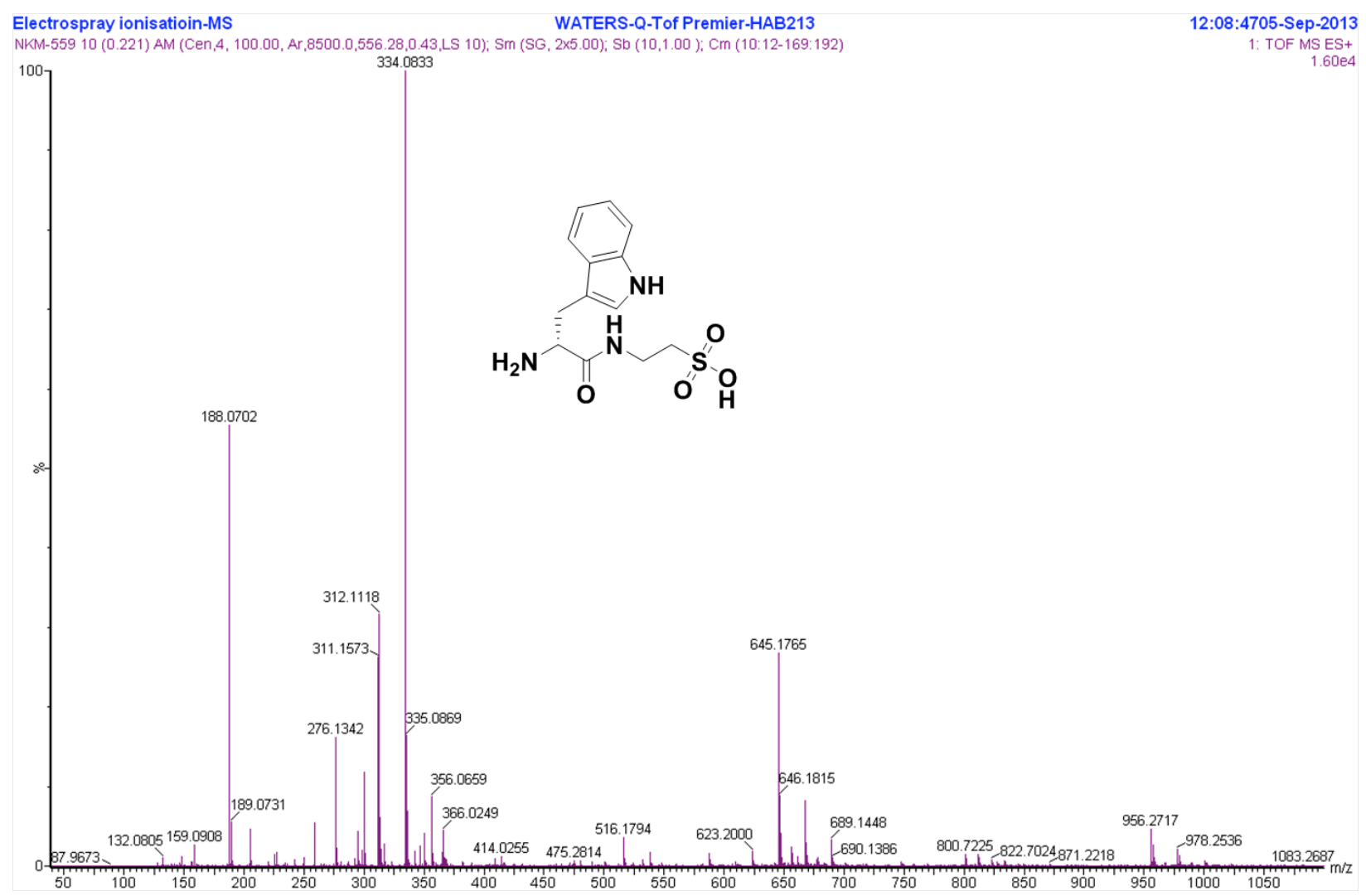

Figure S14: HRMS-ESI of HPLC purified compound D1 
Electrospray ionisatioin-MS

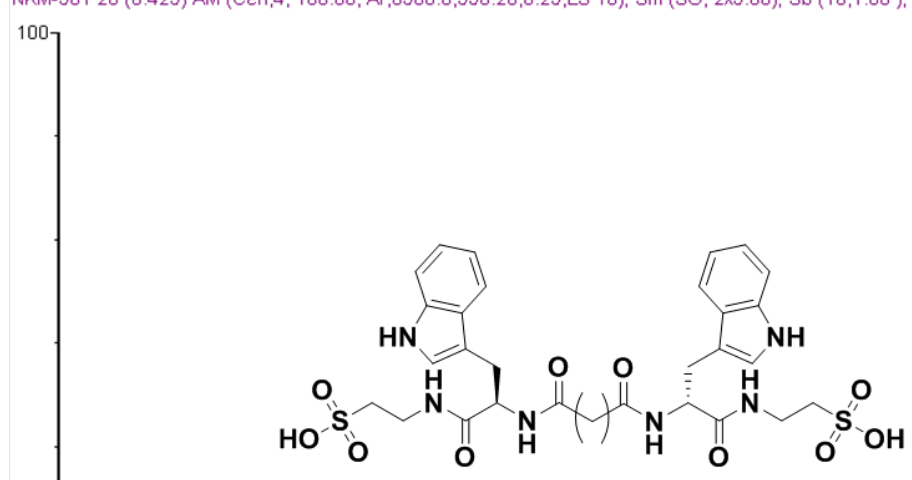

10:47:2406-Sep-2013

1: TOF MS ES+

$5.70 \mathrm{e} 3$

Figure S15: HRMS-ESI of HPLC purified compound D2. 


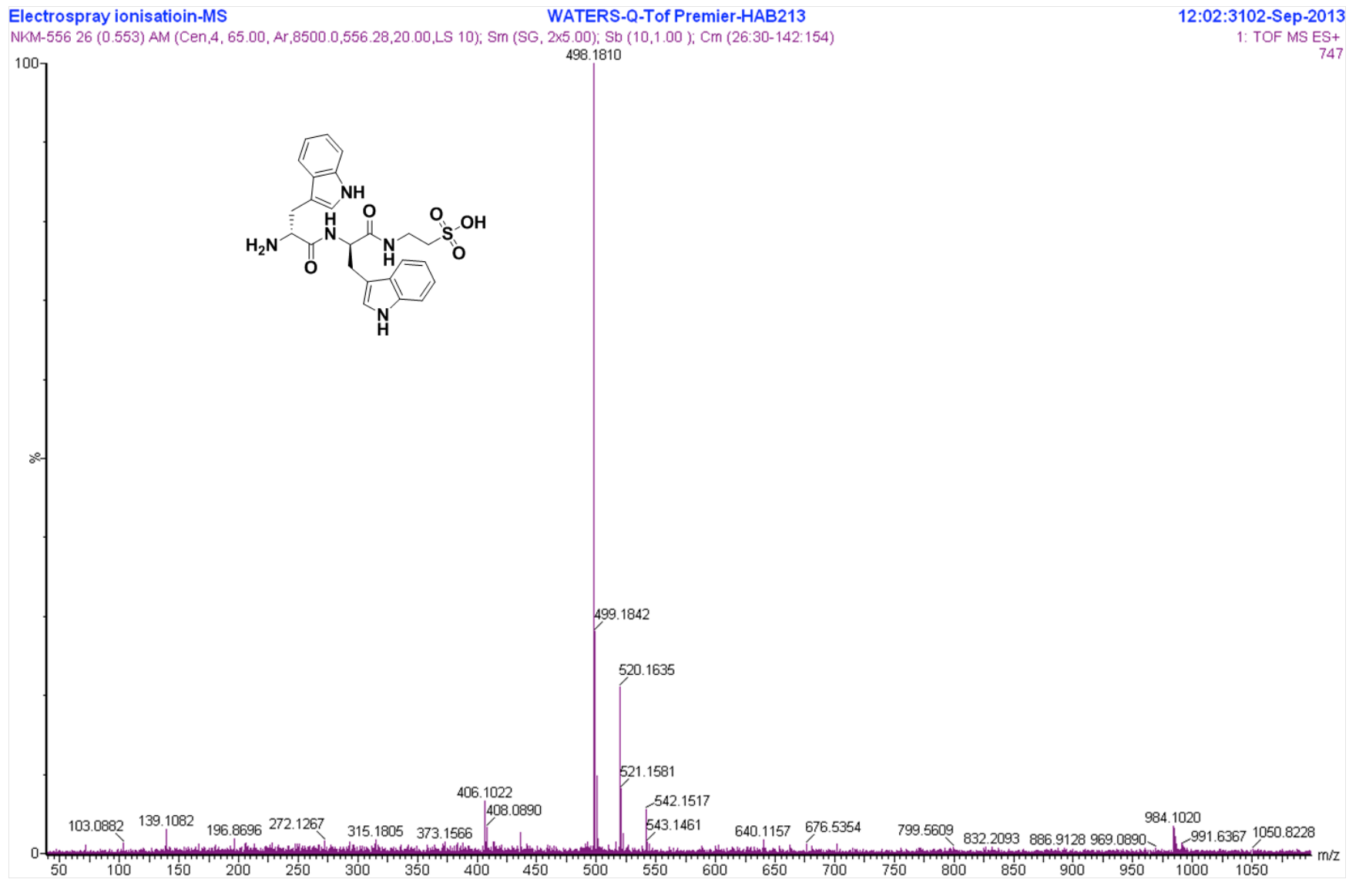

Figure S16: HRMS-ESI of HPLC purified compound D3. 


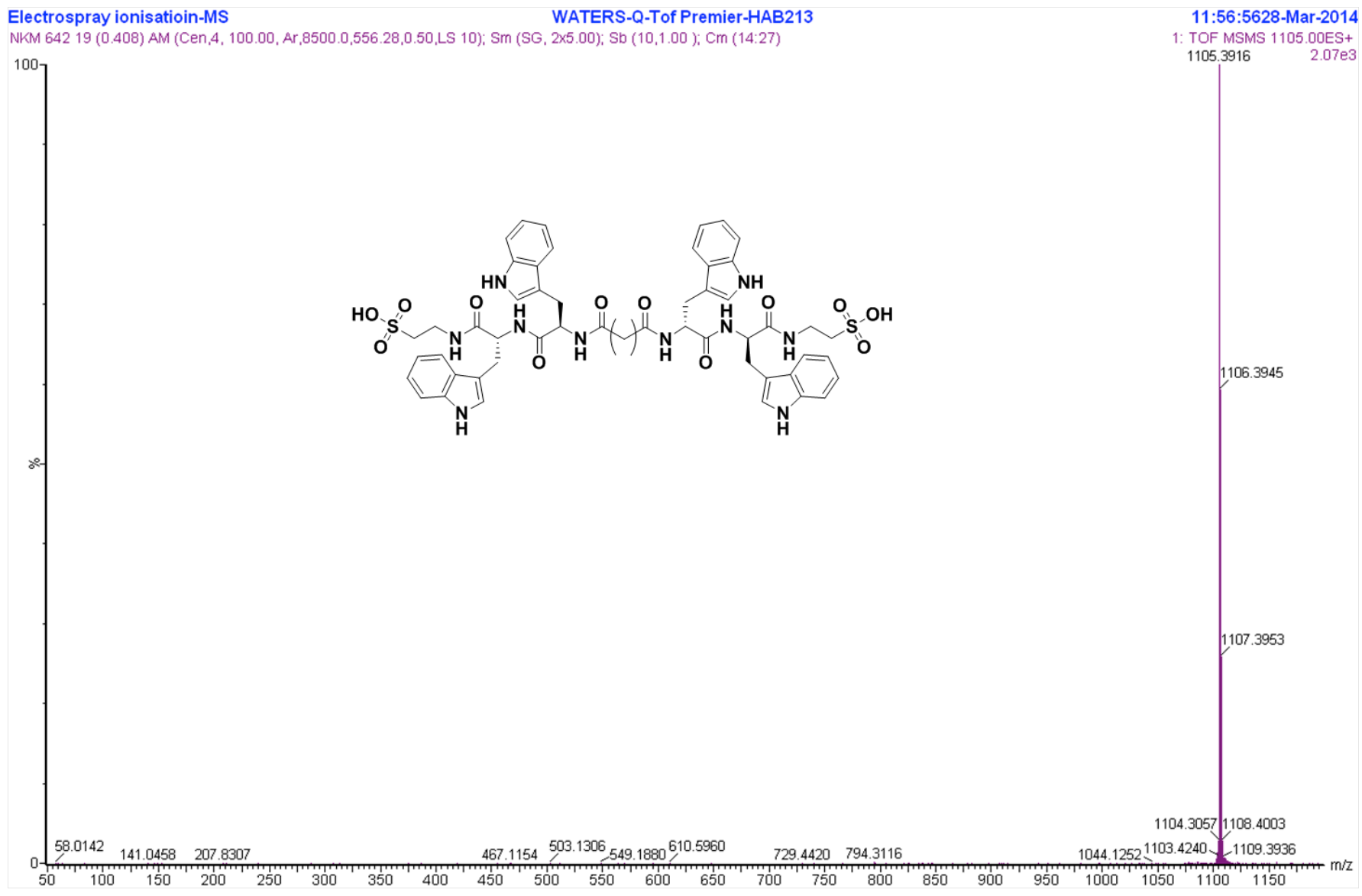

Figure S17: HRMS-ESI of HPLC purified compound D4. 


\section{Appendix: ${ }^{1} \mathrm{H}$ NMR and ${ }^{13} \mathrm{C}$ NMR spectra of conjugates D1-D4:}

Figure S18 : ${ }^{1} \mathrm{H}$ NMR Spectra of Compound D1

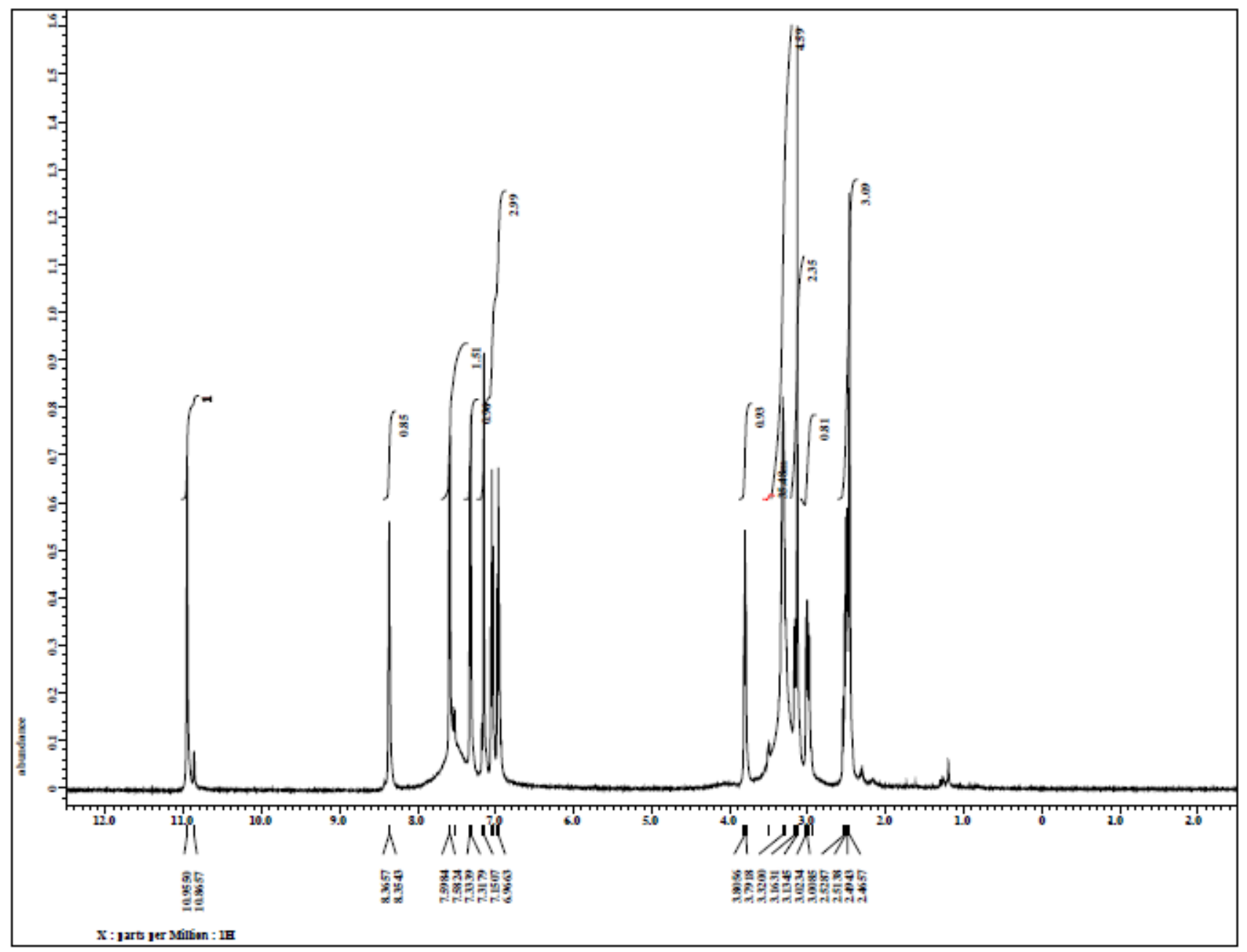


Figure S19 : ${ }^{1}$ H NMR Spectra of Compound D2

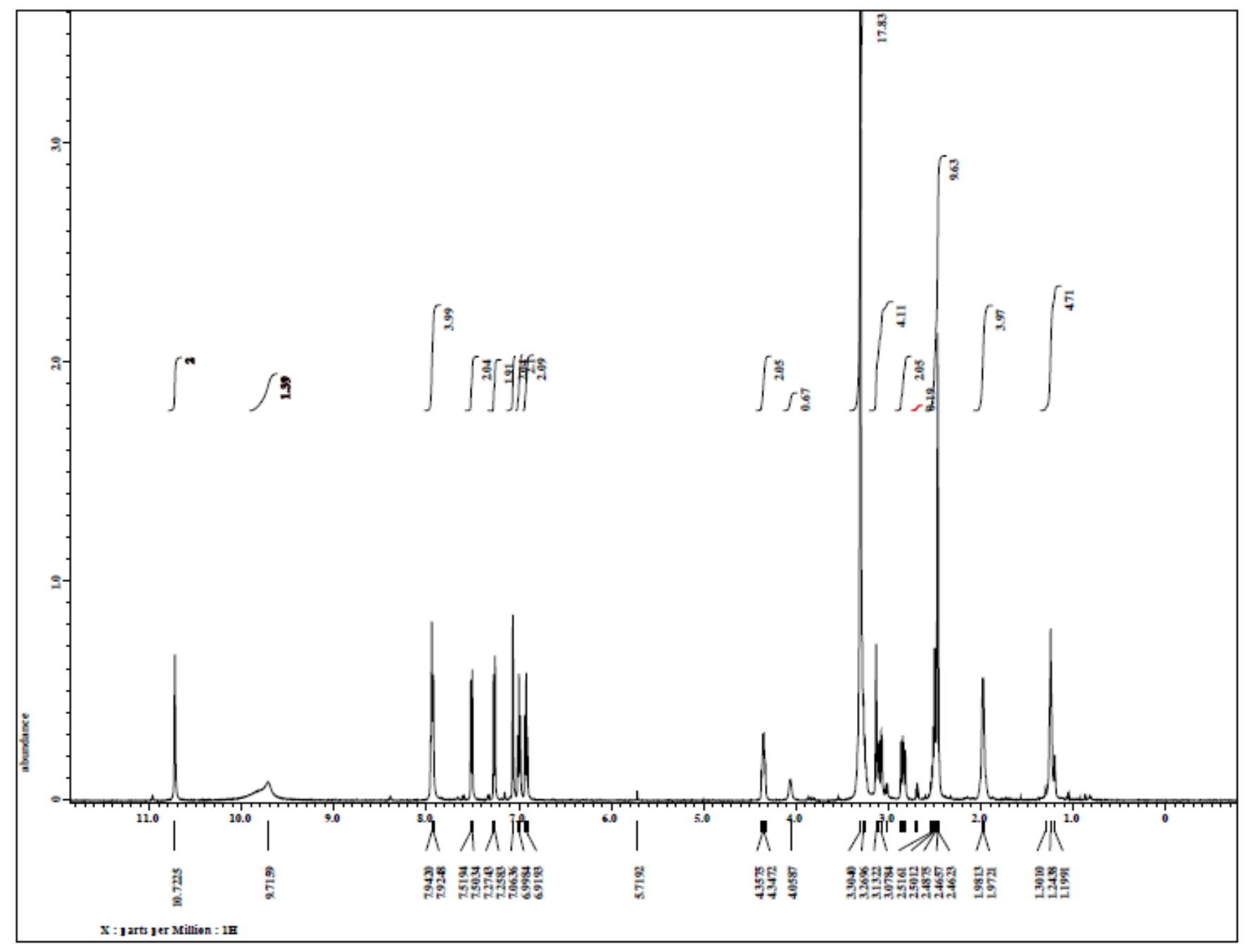


Figure S20 : ${ }^{1} \mathrm{H}$ NMR Spectra of Compound D3

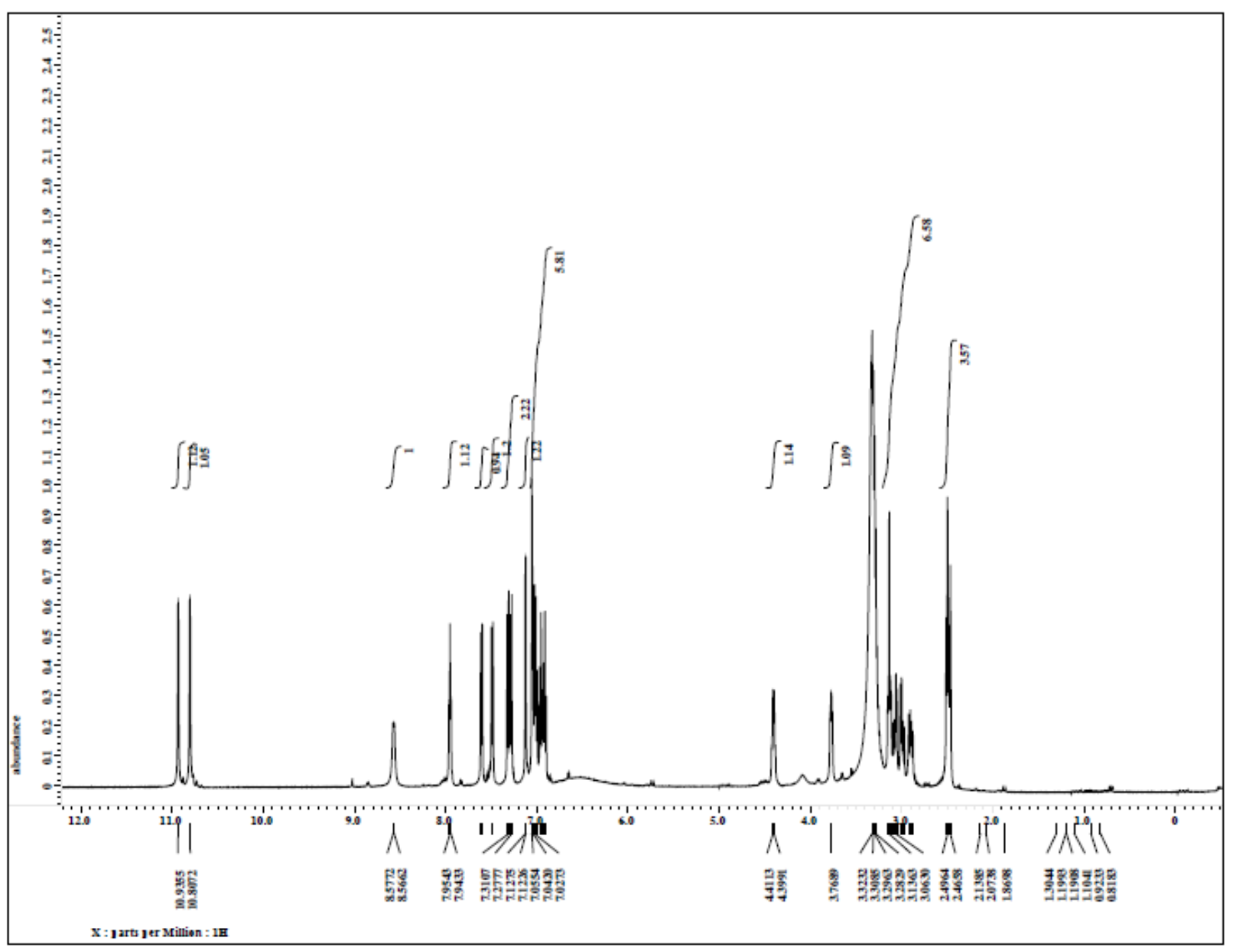


Figure S21 : ${ }^{1}$ H NMR Spectra of Compound D4

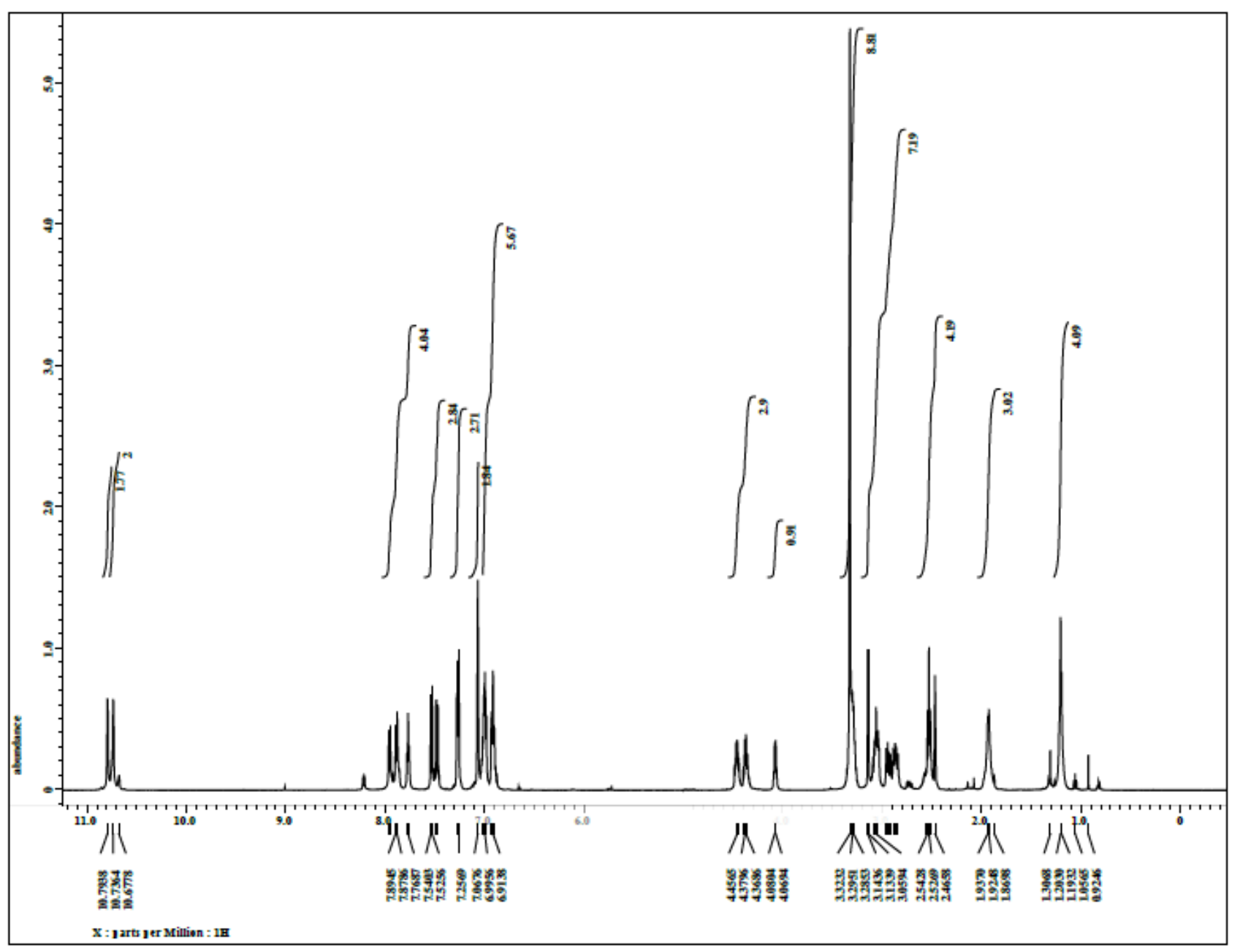


Figure S22 : ${ }^{13} \mathrm{C}$ NMR Spectra of Compound D1

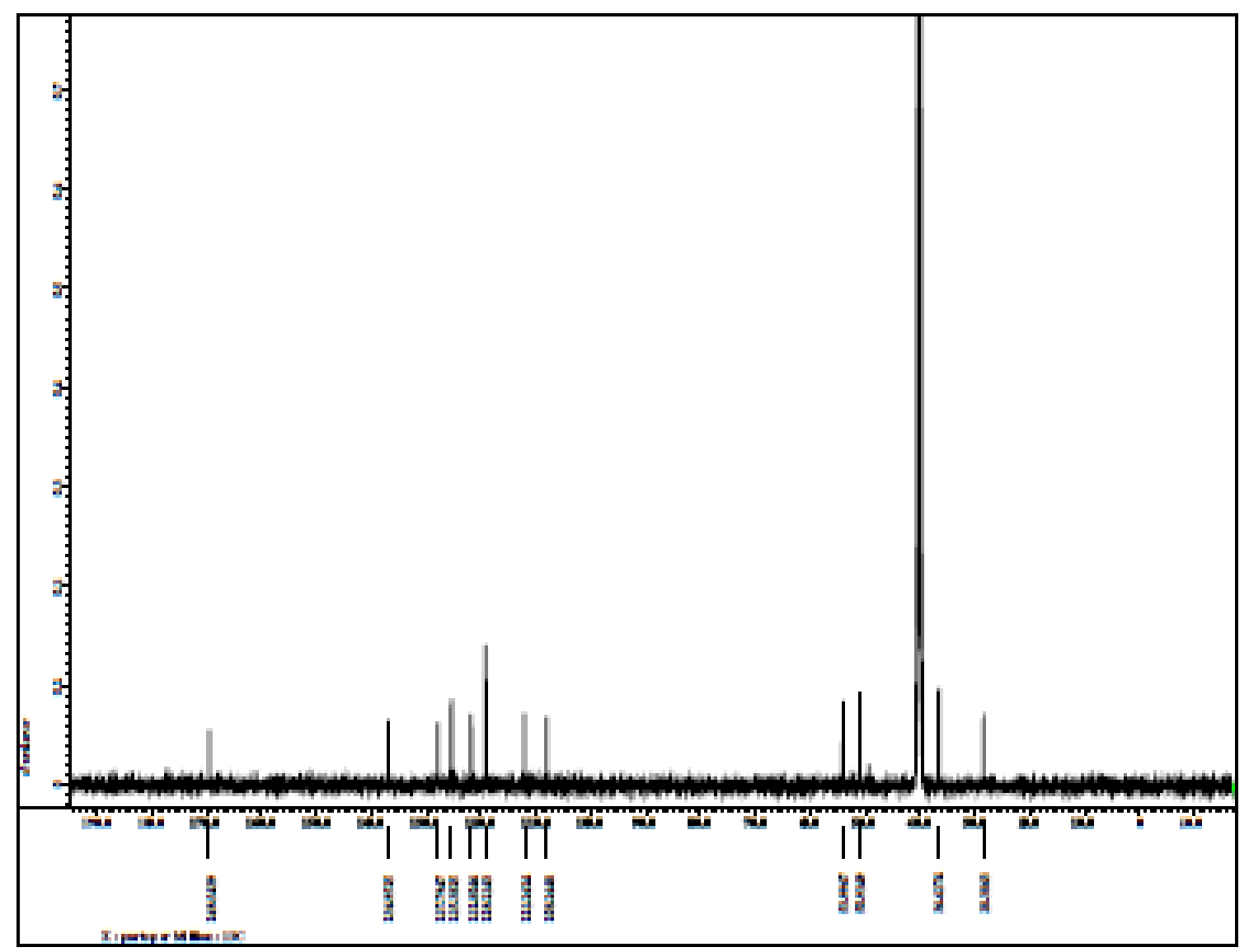


Figure S23 : ${ }^{13} \mathrm{C}$ NMR Spectra of Compound D2

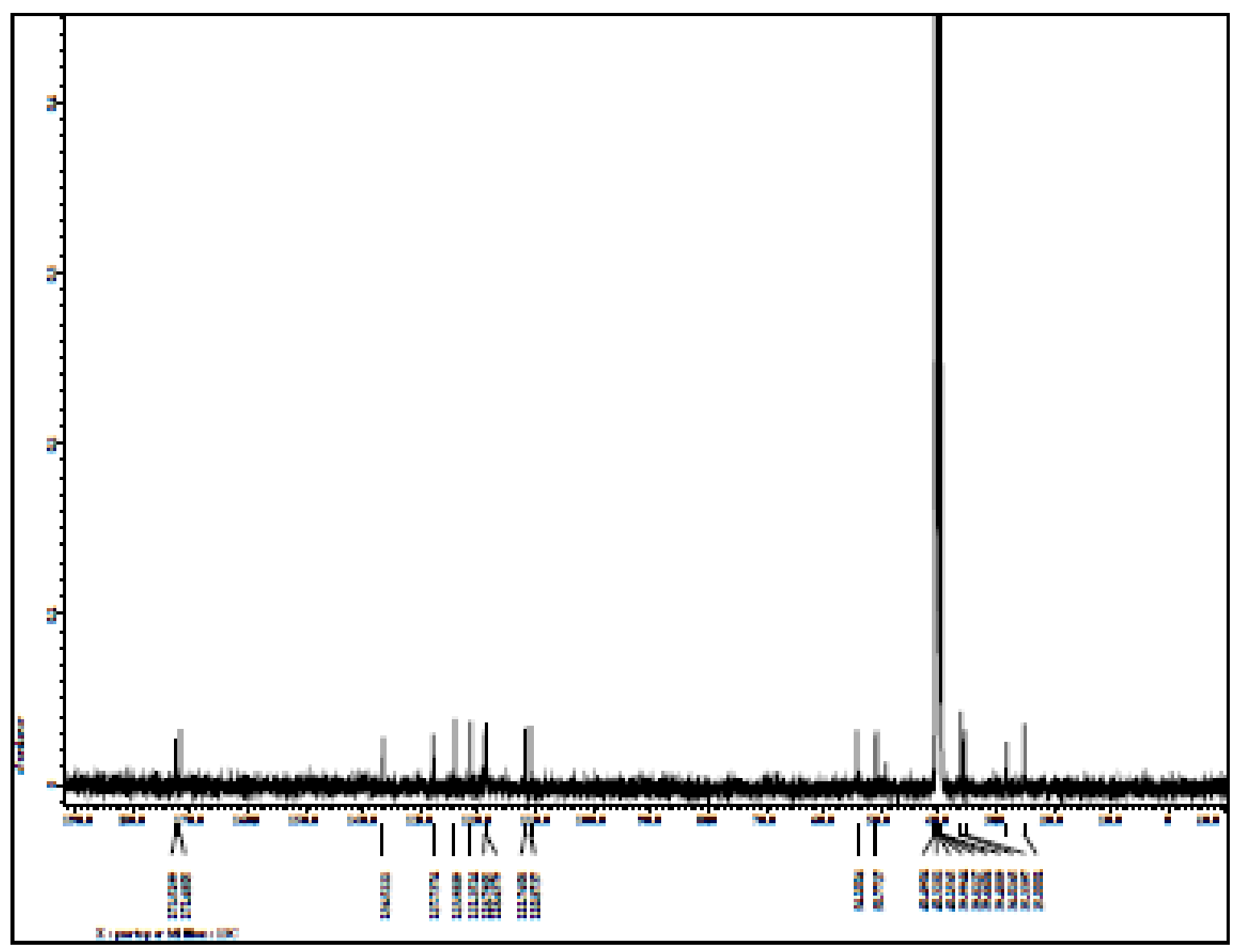


Figure S24 : ${ }^{13} \mathrm{C}$ NMR Spectra of Compound D3.

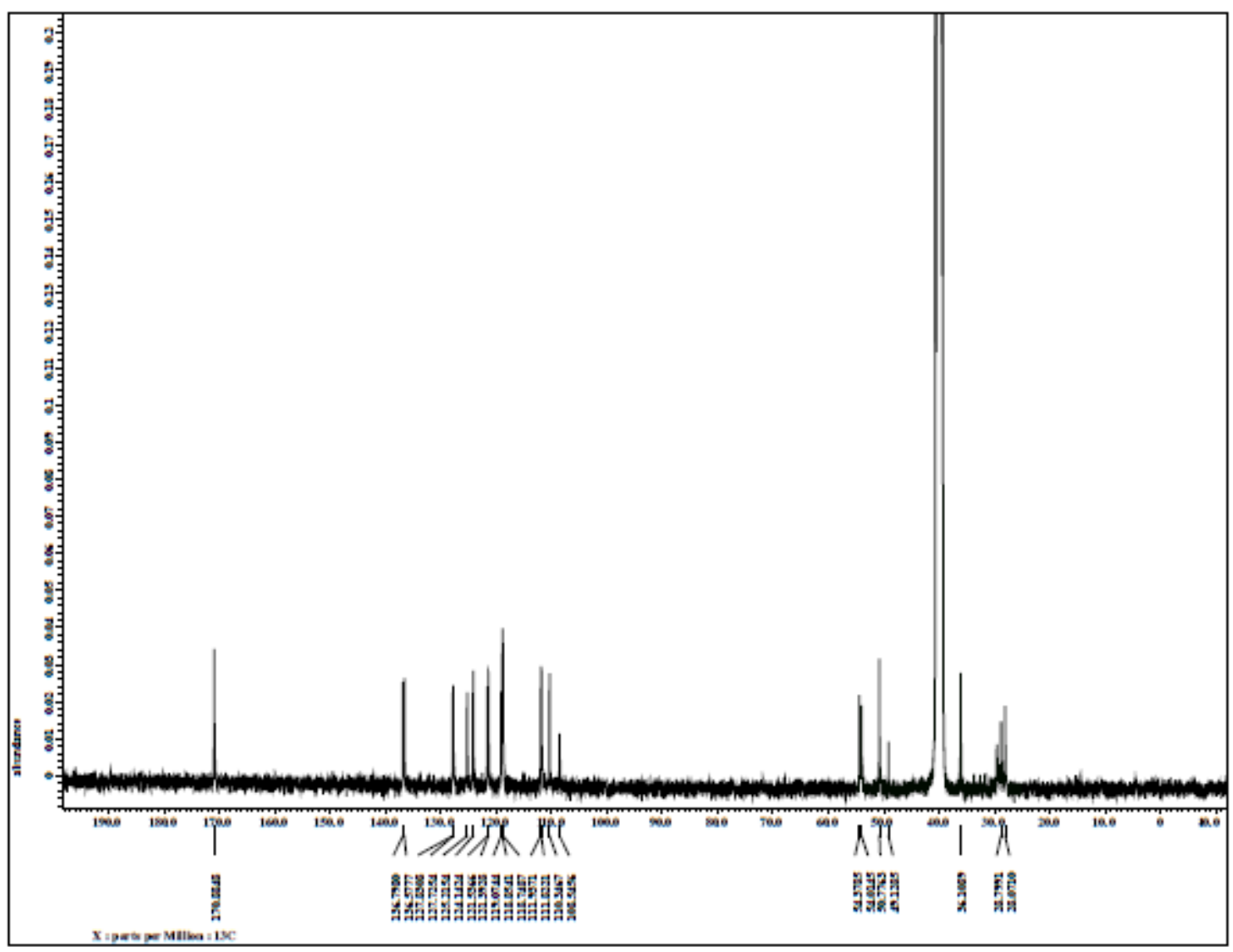


Figure S25 : ${ }^{13} \mathrm{C}$ NMR Spectra of Compound D4.

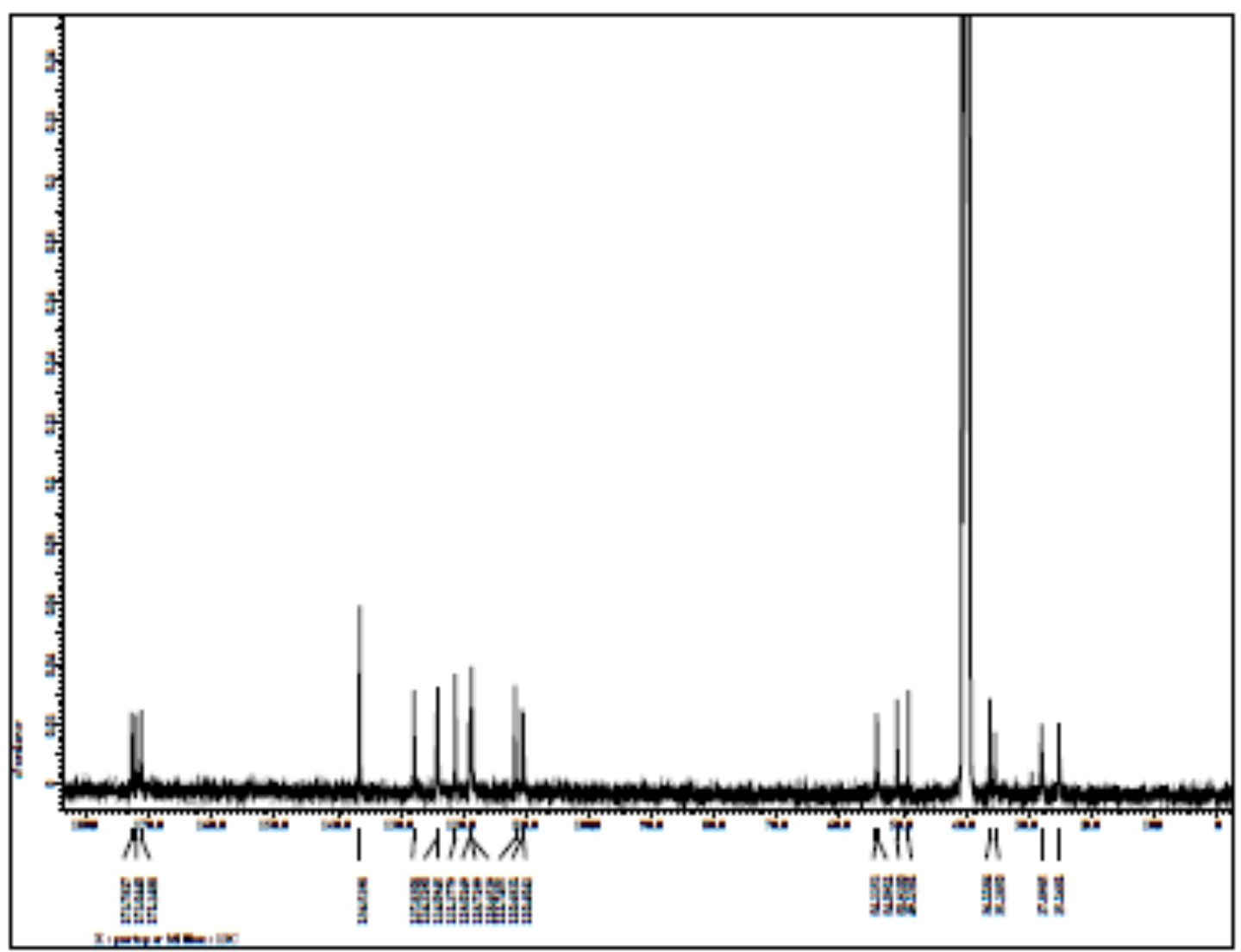


Figure S26: RMSD Profiles
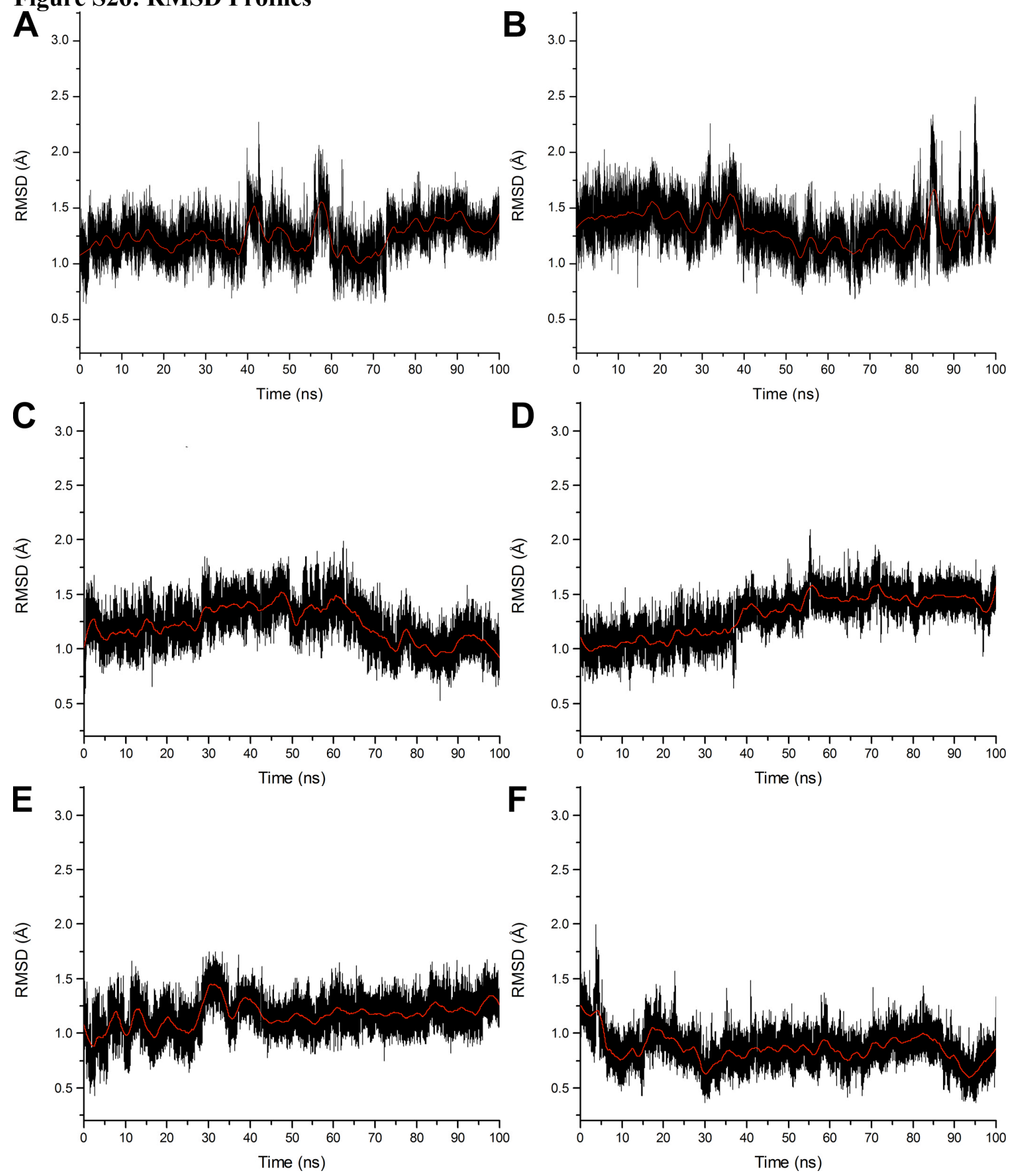

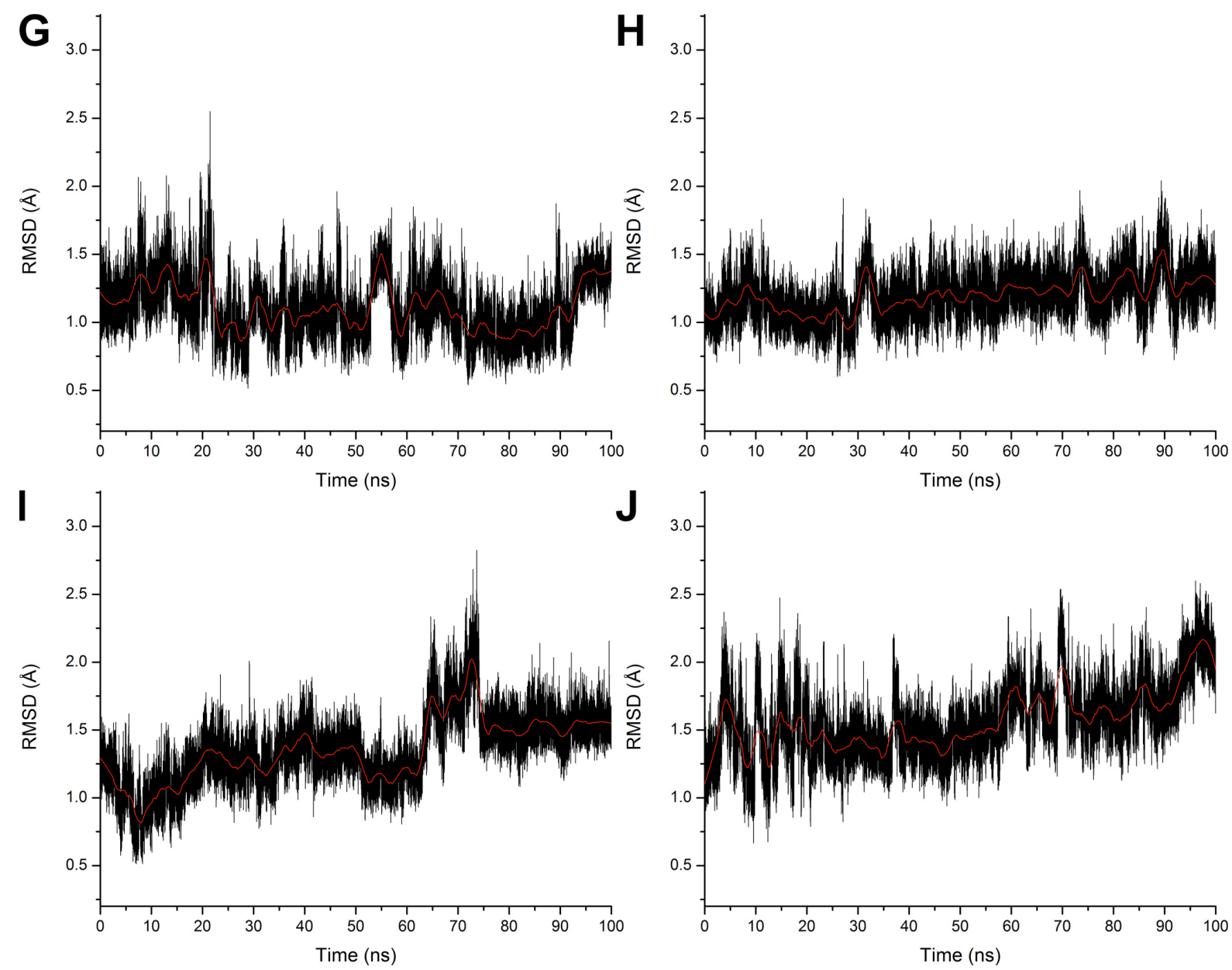

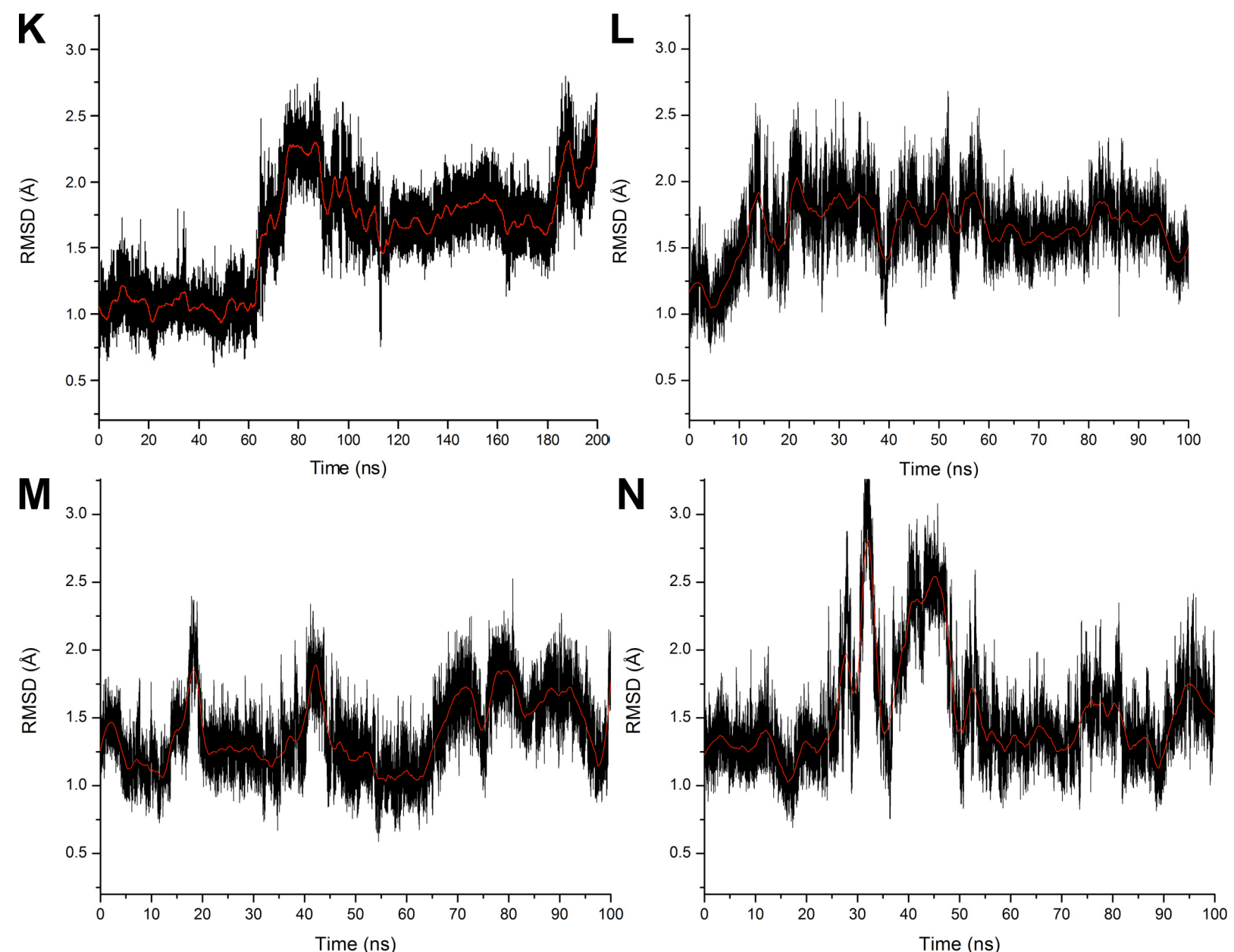

Figure S26: MD trajectories of RMSD profiles are shown for (A) Apo-I, (B) Apo-II, (C) System I, (D) System II, (E) System III, (F) System IV, (G) System V, (H) System VI, (I) System VII, (J) System VIII, (K) System IX, (L) System X, (M) System XI, and (N) System XII. The profile shown in red represents the moving average calculated using Savitzky-Golay method ${ }^{6}$ with a window size of $5 \mathrm{~ns}$. 
Figure S27:
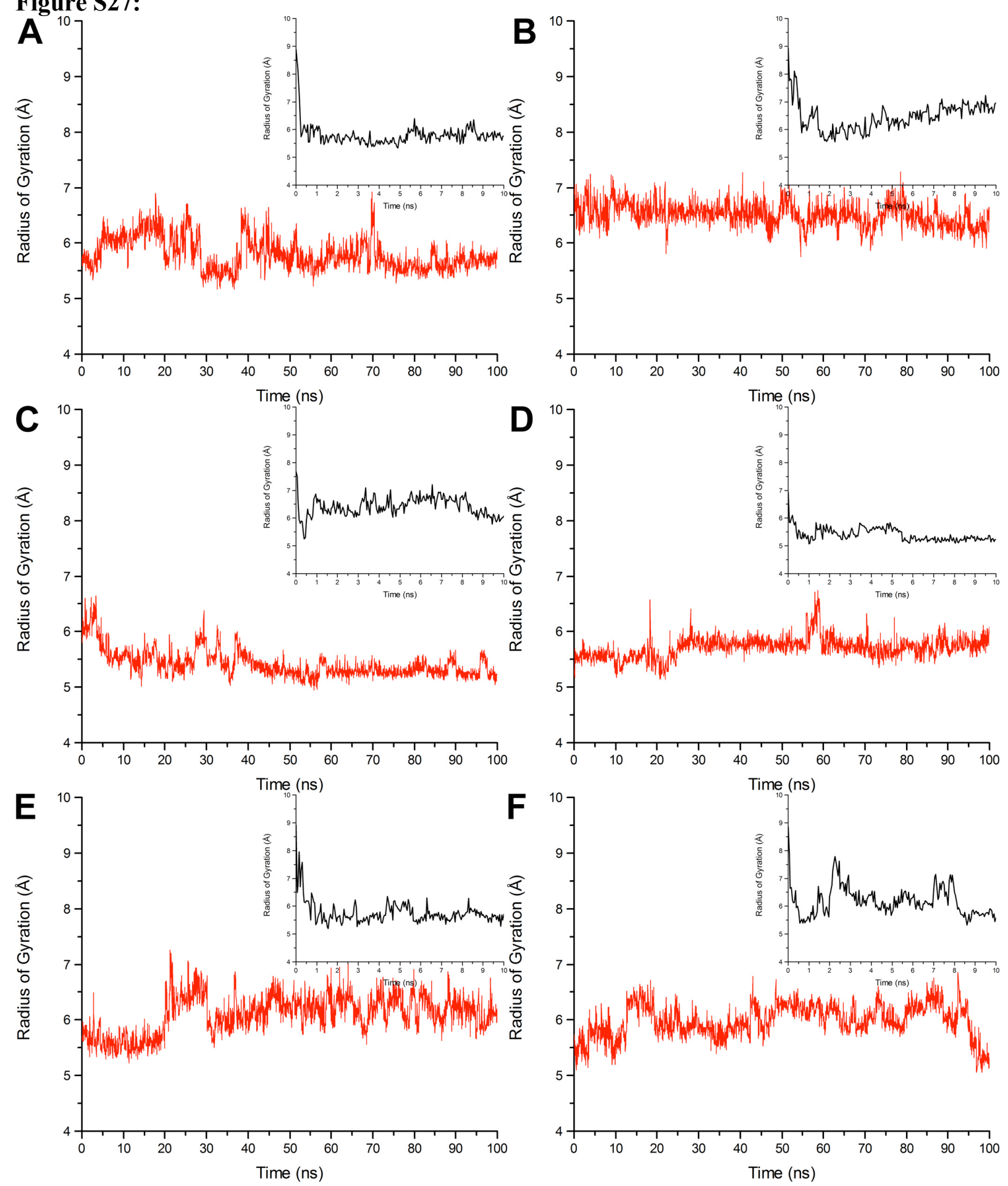

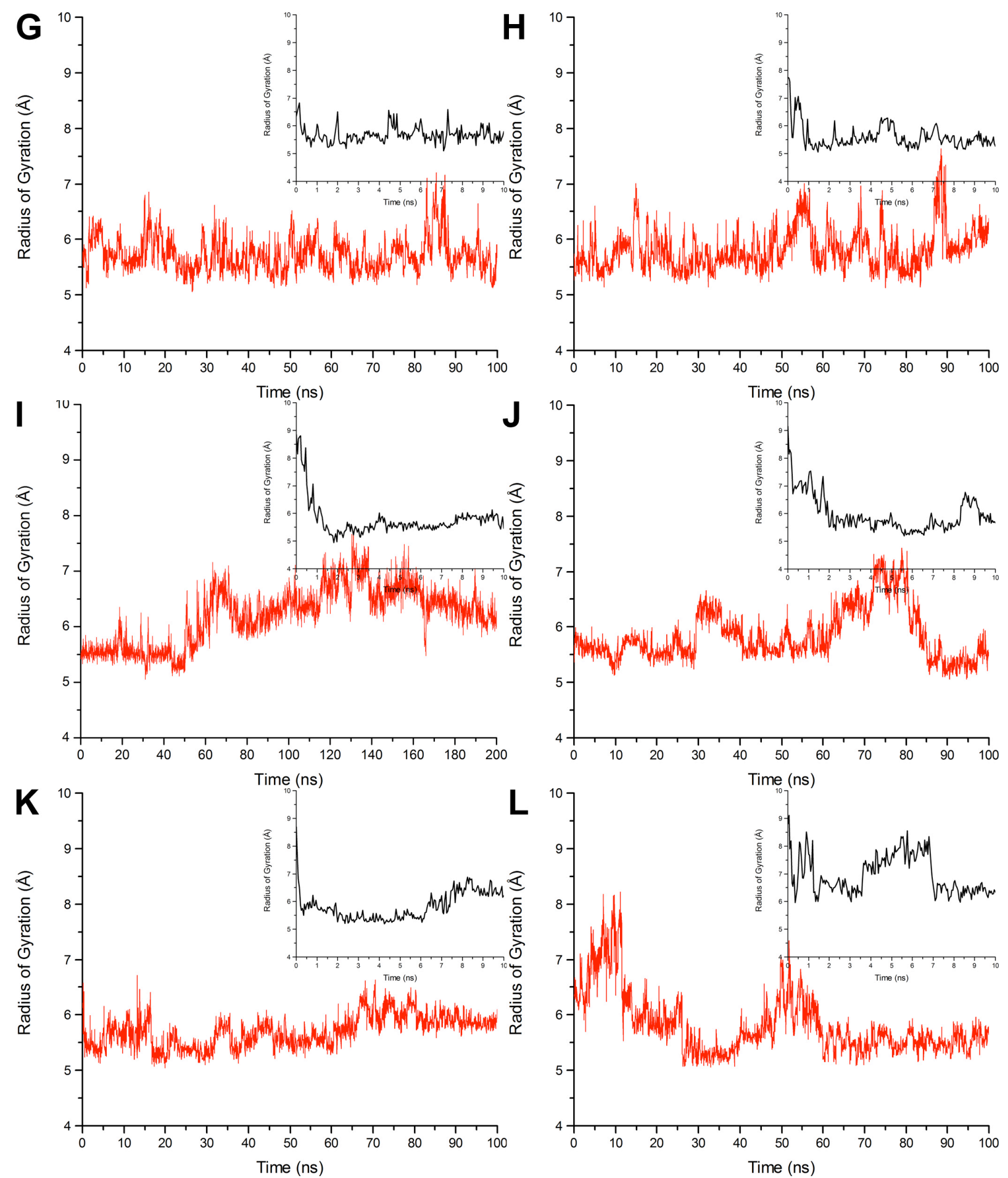

Figure S27: MD trajectories of radius of gyration values calculated for the D4 inhibitor molecule for (A) System I, (B) System II, (C) System III, (D) System IV, (E) System V, (F) System VI, (G) System VII, (H) System VIII, (I) System IX, (J) System X, (K) System XI and (L) System XII. The inset in each panel shows the same data during equilbration. 


\section{Figure S28:}
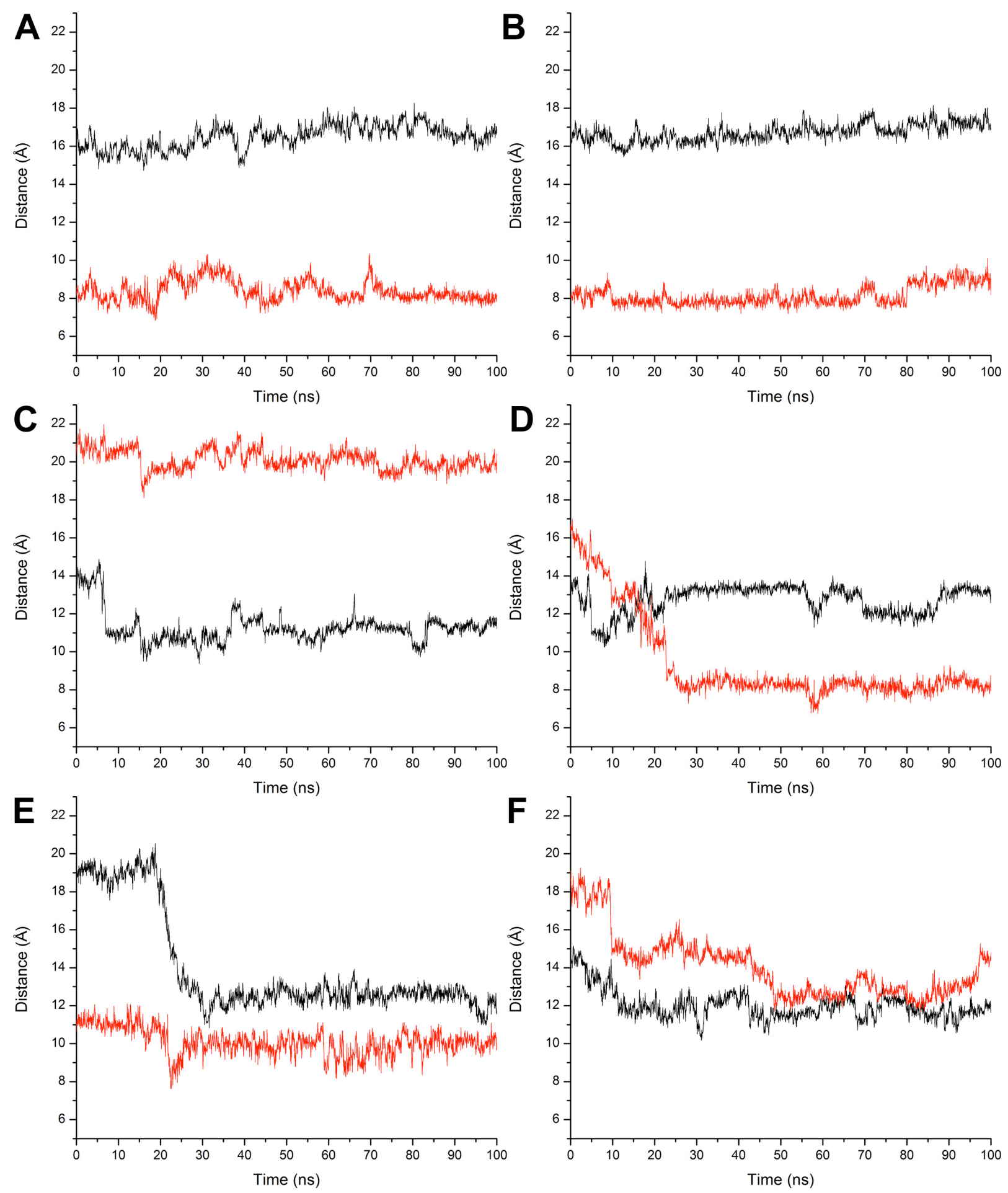

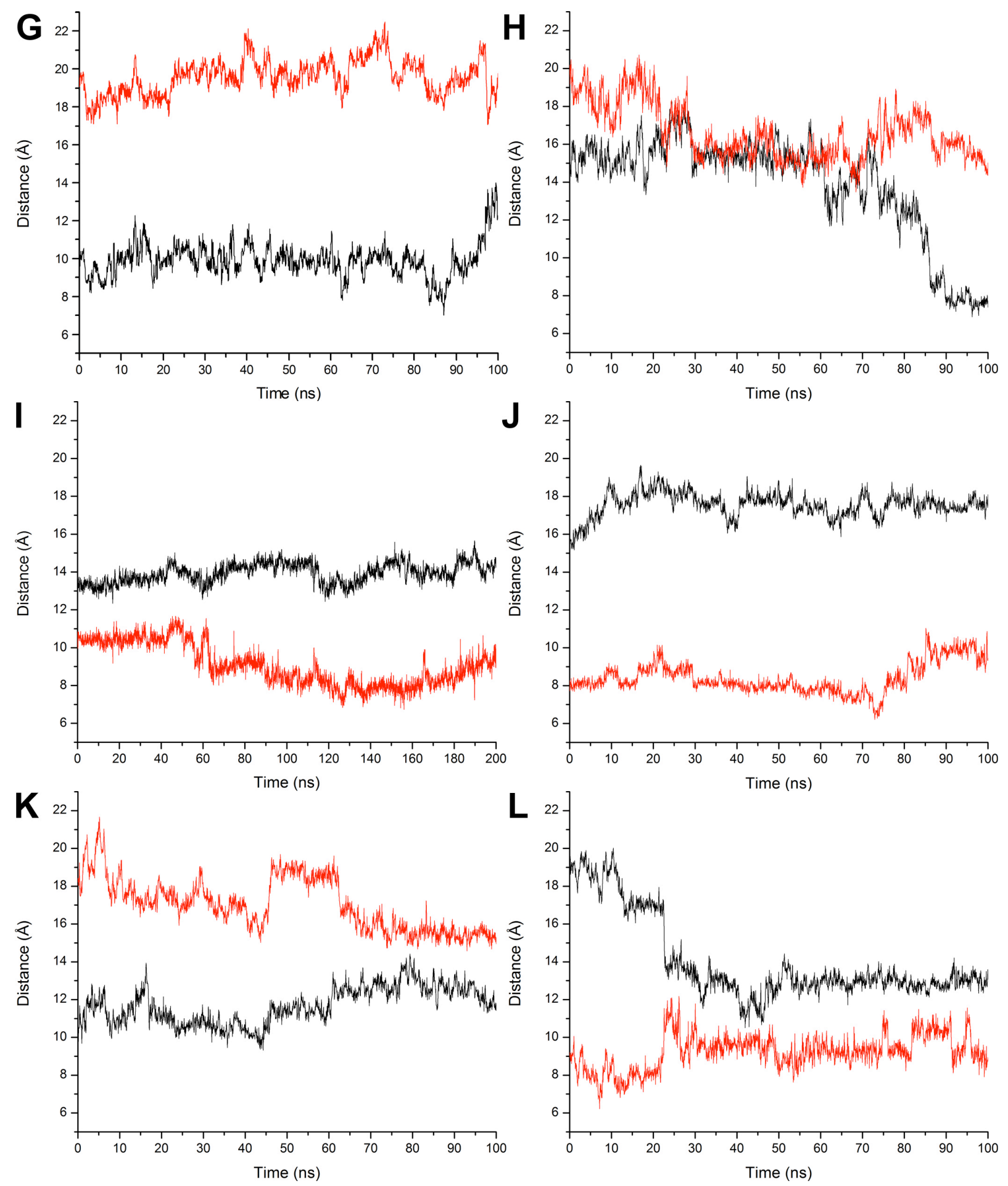

Figure S28: MD trajectories of Center of Mass distances between D4 and helical region(s) of chain A (black) and chain B (red) for (A) System I, (B) System II, (C) System III, (D) System IV, (E) System V, (F) System VI, (G) System VII, (H) System VIII, (I) System IX, (J) System X, (K) System XI and (L) System XII. 


\section{References :}

1. S. Ghosh, M. Reches, E. Gazit, S. Verma, Angew. Chem. Int. Ed. 2007, 119, 20022004.

2. S. Ghosh, S. Verma, Tetrahedron 2008, 64, 6202-6208

3. S. Ghosh, S. K. Singh, S. Verma, Chem. Commun. 2008, 2296-2298

4. A. K. Barman, S. Verma, Chem. Commun. 2010, 46, 6992-6994

5. N.K. Mishra, K. B. Joshi, S. Verma, Mol. Pharm. 2013, 10, 3903-3912.

6. A. Savitzky, M.J.E. Golay, Anal. Chem. 1964, 36 (8), 1627-39.

7. V. Munoz, F. J. Blanco, L. Serrano, Protein Sci., 1995, 4, 1577-1586.

8. C. A. Rohl et al., Biochemistry 1997, 36, 8435-8442. 